Florida International University FIU Digital Commons

$11-15-2013$

\title{
The McSweeney's Group: Modernist Roots and Contemporary Permutations in Little Magazines
}

Charles J. Crespo

ccres018@fiu.edu

DOI: $10.25148 /$ etd.FI13120418

Follow this and additional works at: https:// digitalcommons.fiu.edu/etd

Part of the English Language and Literature Commons, and the Film and Media Studies Commons

\section{Recommended Citation}

Crespo, Charles J., "The McSweeney's Group: Modernist Roots and Contemporary Permutations in Little Magazines" (2013). FIU Electronic Theses and Dissertations. 985.

https:// digitalcommons.fiu.edu/etd/985 


\title{
FLORIDA INTERNATIONAL UNIVERSITY
}

Miami, Florida

\section{THE MCSWEENEY'S GROUP: MODERNIST ROOTS AND CONTEMPORARY PERMUTATIONS IN LITTLE MAGAZINES}

\author{
A thesis submitted in partial fulfillment of \\ the requirements for the degree of \\ MASTER OF ARTS \\ in \\ ENGLISH \\ by
}

Charles J. Crespo

2013 
To: Dean Kenneth G. Furton

College of Arts and Sciences

This thesis, written by Charles J. Crespo, and entitled The McSweeney's Group: Modernist Roots and Contemporary Permutations in Little Magazines, having been approved in respect to style and intellectual content, is referred to you for judgment.

We have read this thesis and recommend that it be approved.

Heather Blatt

Michael P. Gillespie

Nathaniel Cadle, Major Professor

Date of Defense: November 15, 2013

The thesis of Charles J. Crespo is approved.

Dean Kenneth G. Furton
College of Arts and Sciences

Dean Lakshmi N. Reddi University Graduate School

Florida International University, 2013 


\title{
ABSTRACT OF THE THESIS \\ THE MCSWEENEY'S GROUP: MODERNIST ROOTS AND CONTEMPORARY PERMUTATIONS IN LITTLE MAGAZINES
}

\author{
by
}

\section{Charles J. Crespo}

Florida International University, 2013

Miami, Florida

\section{Professor Nathaniel Cadle, Major Professor}

The purpose of this project centered on the influential literary magazine Timothy McSweeney's Quarterly Concern. Using Bruno Latour's network theory as well as the methods put forth by Robert Scholes and Clifford Wulfman to study modernist little magazines, I analyzed the influence McSweeney's has on contemporary little magazines. I traced the connections between McSweeney's and other paradigmatic examples of little magazines - The Believer and n+1 — to show how the McSweeney's aesthetic and business practice creates a model for more recent publications.

My thesis argued that The Believer continues McSweeney's aesthetic mission. In contrast, $n+1$ positioned itself against the McSweeney's aesthetic, which indirectly created a space within the little magazines for writers, philosophers, and artists to debate the prevailing aesthetic theories of the contemporary period. The creation of this space connects these contemporary magazines back to modernist little magazines, thereby validating my decision to use the methods of Scholes and Wulfman. 


\section{TABLE OF CONTENTS}

CHAPTER

PAGE

INTRODUCTION

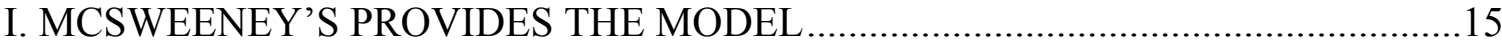

II. TWO PATHS EMERGE FROM THE MCSWEENEY'S MODEL ….........................57

CONCLUSION 


\section{INTRODUCTION}

With their 2010 book Modernism in the Magazines: An Introduction, Robert Scholes and Clifford Wulfman made a major contribution to the emerging field of periodical studies, a field that was further legitimized with the establishment of an academic journal, the Journal of Modern Periodical Studies, in the same year. Part of the reason for the recent emergence of the field, as Sean Latham and Scholes point out in their essay "The Rise of Periodical Studies," is that "this development is being driven by the cultural turn in departments of language and literature, by the development of digital archives that allow for such studies on a broader scale than ever before."1 In other words, scholars now have unprecedented access to a broad range of periodicals online and are "finding in periodicals both a new resource and pressing challenge to existing paradigms for the investigation of Enlightenment, nineteenth-century, and modern cultures.... Every year new books are appearing that emphasize periodicals and investigate the ways in which modern literature and the arts are connected to the culture of commerce and advertising and to the social, political, and scientific issues of the time."2 Yet what exactly do these scholars mean by the term "periodical"? For the purposes of my work, I will define a periodical as a print project that involves a substantial circulation at some point during its run.

The majority of the work done so far in the field has focused on a subgroup of periodicals: the so-called "little magazines," small circulation magazines that have catered toward a niche market that is invested in serious avant-garde literary

\footnotetext{
${ }^{1}$ Sean Latham and Robert Scholes, “The Rise of Periodical Studies," PMLA 121, no. 3 (2006): 517. ${ }^{2}$ Ibid.
} 
experimentation. Further, this focus has largely been on "little magazines" of the modernist era, for example Poetry, Blast, and The Little Review. ${ }^{3}$ However, after closely studying the last two decades, I contend that we are in the midst of a second golden age of little magazines, marked by the reestablishment of the periodical as the arena for artists, writers, and critics to debate the aesthetics of the present day.

My work here will center on this second generation of little magazines, with a focus on what I will call "The McSweeney's Group," a term that emphasizes the central importance of the influential little magazine Timothy McSweeney's Quarterly Concern as well as other recent little magazines that have positioned themselves alongside of or in opposition to McSweeney's. Apart from McSweeney's, this group includes The Believer, n+1, The Baffler, Might Magazine, Ampersand Magazine, Lucky Peach, Grantland Quarterly, The Point Magazine, Jacobin, and The New Inquiry; however, in this thesis I will be focusing primarily on what I consider to be the paradigmatic examples:

McSweeney's, The Believer, and $n+1$. I propose not only to examine what led to the rise of The McSweeney's Group, but also to show that the methods Scholes and Wulfman use to study modernist magazines are helpful in studying the "little magazines of today." For the purposes of my study, I will focus on the years from 1998-2000 of McSweeney's, and the years 2003-2004 for The Believer and $n+1$, which I contend demonstrates the cross-pollination within The McSweeney's Group most fully.

As I will argue in the first chapter, McSweeney's is at the heart of the second golden age of little magazines for three distinct but related reasons. First, McSweeney's

\footnotetext{
3 The Journal of Modern Periodical Studies, for example, only considers magazines from the years 18801950.
} 
provided a model for how a small print-first magazine can succeed in an ever-increasing digital market. The McSweeney's model has since been copied repeatedly by a number of little magazines thriving today. Second, McSweeney's was equally important to this generation of little magazines in terms of creating an influential aesthetic. The aesthetic has resounded through the world of little magazines in terms of both the formal design of the magazines themselves and content contained within them. Finally, McSweeney's editor and driving force Dave Eggers has been the "ideal editor"4 for a periodical, according to Matthew Philpotts' definition. Philpotts defines the ideal editor as "not only a poet and a professional, but also a politician and a profiteer, a prophet and a publicist; less a double personage than a multiple personage," that I will contend Eggers has been for McSweeney's. Viewing Eggers in this way is not only important to understanding his place among his contemporaries, but also to understanding his incredible influence on this age of periodicals through his editorship of McSweeney's.

The second chapter will focus on the two major magazines that I view as vital actants within The McSweeney's Group. Although there are other contemporary little magazines that have been influenced by McSweeney's, The Believer and $n+1$ are valuable in that they represent two major paths that contemporary magazines followed in the wake of McSweeney's. The first part of the second chapter will focus on The Believer as an example of a contemporary magazine that positioned itself alongside the McSweeney's

\footnotetext{
${ }^{4}$ Matthew Philpotts, "The Role of the Periodical Editor: Literary Journals and Editorial Habitus," The Modern Language Review 107, no. 1 (2012): 54.

${ }^{5}$ Ibid., 61.
} 
aesthetic, while also following McSweeney's business model. The remainder of this chapter will examine $n+1$ as a contemporary magazine that was clearly influenced by McSweeney's, but chose to position itself against it aesthetically, though it would still follow its business model.

The decision of $n+1$ to position itself against McSweeney's draws a significant parallel to the modernist little magazines. As Scholes and Wulfman contend in Modernism in the Magazines:

The magazines provided a cultural space where these challenging new modes of literature and visual art could appear side by side with other, less extreme modernist modes of expression, and where artists, impresarios, critics, and philosophers could address one another directly, with a segment of the public listening in on those conversations.... There were fierce debates about these matters, with cases being made for and against various modes and styles....And this was modernism. ${ }^{6}$

According to Scholes and Wulfman, the modernist magazines were not only valuable because of the magazines' ability to publish new authors or give established authors a means to publish controversial material, but also because the magazines were primarily valuable as a forum to debate the modes and styles that have since become known as modernism. Similarly, I will contend in the second chapter that The McSweeney's Group has served as a similar forum for contemporary artists, critics, and philosophers to debate the modes and styles of today's aesthetic movement.

\footnotetext{
${ }^{6}$ Robert Scholes and Clifford Wulfman, Modernism in the Magazines (New Haven: Yale University Press, 2010), 74 .
} 
The significance of my study is twofold. First, in closely examining The McSweeney's Group and its role in shaping the second golden age of little magazines, the thesis will fill a surprising gap in the history of criticism of contemporary little magazines. Instead of academic scholarship, popular media outlets or other small magazines have produced most of the criticism that exists on The McSweeney's Group. The interest from the mainstream media demonstrates the appeal and cultural impact that the members of the McSweeney's Group have had both on the culture at large and on print and digital media. With that said, the lack of scholarly interest indicates its openness for serious study.

Although there has been some critical work done with regard to McSweeney's, much of it has used the magazine as a way to make a point in some larger argument. For example, in an essay entitled "Zeroing In on Contemporary, Independent Visual Arts Magazines," Susan E. Thomas glances over McSweeney's as a way to support her conclusion that "The acquisition, promotion, and preservation of independent, contemporary visual arts magazines [by libraries]...inform readers about noncommercial activities off the radar, illuminate the shape of things to come, provide work and employment opportunities, and, not least, inspire all who come in contact with them."7 For Thomas, the recent success of small, independent magazines can be attributed to innovative design elements that digital media simply cannot provide. In Thomas' view, the design of McSweeney's is its most important quality. Thomas' work is emblematic of

\footnotetext{
${ }^{7}$ Susan E. Thomas, "Zeroing In on Contemporary, Independent Visual Arts Magazines," Art Documentation: Bulletin of the Art Libraries Society of North America 26, no. 1 (2007): 45.
} 
the way McSweeney's has been viewed critically. It has been seen as worthy of consideration but only in an ancillary manner.

Second, my thesis will situate the rise of the second golden age of little magazines directly within the postmodern moment and the rise of digital technology. The prevalence of new technologies has challenged the viability of print media with cheaper digital forms of publication. By tracing the influence and successful model of McSweeney's, I hope to answer the question of why little magazines seem to be thriving during a period when all the cultural indicators suggest they should not be.

In my work I will primarily be focusing on the Actor-network theory (ANT) developed by Bruno Latour and Michel Callon. "Theory" is a bit of a misnomer here because ANT could be better described as a methodology for discovering or analyzing relational ties within a given network, which in my case will be The McSweeney's Group. ANT is valuable to this project because it will allow me to map clusters of "actors" and track how each actor joins with the others to form a network. Actor-network theory's value also lies in the fact that it allows for both human and non-human actors, both of which I will designate using the preferred ANT term of "actant." Actor-network theory's use of the term "actant" is crucial to my project because it breaks the associations with agency and intentionality that the term "actor" has. By doing so, ANT allows me to analyze non-human components that are affecting the formation and continued existence of The McSweeney's Group. Without this specificity in ANT's use of terminology, these non-human actants might be ignored due to a perceived lack of agency or intentionality, when in fact they play a notable role in the formation of a network. 
In this way, using ANT will allow me not only to discover the relation between McSweeney's editor and publisher Dave Eggers (actant) and The McSweeney's Group (network), but also how the rise of technology which allowed for online publishing (another actant) may have influenced the formation of The McSweeney's Group (again, network). For this reason, ANT will be particularly helpful in analyzing the factors and demonstrating the relations that led to both the formation of The McSweeny's Group and, in turn, the second golden age of little magazines.

I view this as a primarily methodologically-driven project. I will focus on the "theory" of ANT, but it is not the only way I will be analyzing The McSweeney's Group. For example, I will also be using the methods established by Latham, Scholes, Wulfman, and other scholars who have helped to define the emerging field of periodical studies.

Designed in large part around the work of Scholes and Wulfman, periodical studies has become a well-defined sub-field of literary studies, driven not by any particular theory, but rather by the practice of reading magazines as a distinct genre. By reading magazines as a genre I mean not looking at, for example, an issue of The Little Review through a deconstructive perspective, but rather focusing on both the content and meta-content of the magazine (advertisements, list of contributors, issue number, etc.). In particular, I plan on looking at McSweeney's not just to analyze its content, but also to study its advertisements (or lack thereof), its recurring contributors and their career arcs as well as editor Dave Eggers' career arc and major aesthetic preoccupations. I will cross-reference these contributors and advertisements to see how they contributed to The Believer and $n+1$. Reading magazines in the fashion of Scholes and Wulfman gives us, 
as they note, "a unique ability to bring social, political and aesthetic history to life" 8 in ways that reading a single issue cannot, because it allows us not only to understand but to follow the debates about politics, culture, and literary criticism as they developed over time. My project will extend this emerging field of periodical studies in two ways. First, my project will display how incorporating ANT can complement the methodological goals of periodical studies. Second, I will shift the focus toward much more recent little magazines, which have virtually been untouched by scholars.

At the center of this work lies McSweeney's founder and editor Dave Eggers. Prior to founding McSweeney's, Eggers, along with his friend and co-editor David Moodie, had co-founded Might Magazine, ${ }^{9}$ which was, in many ways, a precursor to McSweeney's. Might seems to defy classification as either a little magazine or as a "mass magazine.” Rather, it has components of both, and a brief examination of it will help clarify not only its importance to understanding McSweeney's, but also its importance in understanding Eggers' career path. In addition, this brief overview of Might will demonstrate the methodologies that will drive the rest of my project.

Might was an independent bimonthly magazine that released its first issue in 1994. Eggers and Moodie described the first issue as a "really earnest angsty-youth-kindof-thing" ${ }^{10}$ in an interview with Mother Jones in 1997. Though the magazine would

\footnotetext{
${ }^{8}$ Scholes and Wulfman, Modernism in the Magazines, 167.

${ }^{9}$ From this point referred to simply as Might

${ }^{10}$ Leah Shahum, "Media Picks," Mother Jones, July/August 1997, http://www.motherjones.com/media/1997/07/media-picks.
} 
begin with that "angsty" voice, it changed significantly for the second issue, something Eggers wrote about in his memoir A Heartbreaking Work of Staggering Genius:

In the month or so since that first issue, Might has become something different.... Yes, we still care about changing the lives of our peers, and of course the world, and still expect at some point to be sent into space, but on the other hand...we have narrowed our scope and sharpened our knives. We have targets now, we have decided upon good guys and bad guys, friends and enemies (obstacles). We begin a pattern of almost immediate opinion-reversal and self-devouring. Whatever the prevailing thinking, especially our own, we contradict it, reflexively.... And because the general public will not believe that we have been chosen to articulate the hopes and fears of a people, to speak for them and everyone and make history, we set out to see what they will believe. ${ }^{11}$

Although the earnestness of the first issue would remain, Might's voice would also incorporate anger, sarcasm, irony, and humor for the remainder of its run. This shift in tone is significant because a similar change in tone would occur after the initial issue of McSweeney's as well.

Notably, Might shares both a leading editor and status as an independent magazine with McSweeney's, along with an affinity for placing text in locations that are often left unused or underused by other publications. In the February/March 1996 issue,

\footnotetext{
${ }^{11}$ Dave Eggers, A Heartbreaking Work of Staggering Genius (New York: Vintage, 2001), 240-241.
} 
for example, the editors placed the phrase, "Page numbers are overrated,"12 where the page number should be in the bottom right-hand corner, as well as "REMEMBER THE NEEDIEST!" on the corresponding left-hand corner of the same page. There is no explanation given for either of these two phrases and, as the issue continues, some of the pages are numbered while others are not. The concern for text (as we will see) clearly stems from the influence of Eggers. What they also share - perhaps most importantly - is a similar tone.

A primary aspect of that tone is humor, both self-effacing and whimsical. Selfeffacing humor can be seen in that same February/March issue of Might, which has a footnote under an article about pranking directory assistance operators in its first section that reads, "Why another phone prank? How can any magazine justify such unoriginal frivolity? Good question. Well, we have no real good excuse.... Forgive us, and we will forgive you for your sundry mistakes and faults." ${ }^{\text {"13 }}$ Similarly, on the copyright page of the Autumn 1998 issue of McSweeney's Eggers notes, “This journal has been proofread, but not by paid professionals." "In that same issue of Might, a bit of whimsical humor can be seen in a small article that is simply a list of "things" that rhyme with "Shalikashvilli"; a sample of these "things" are, according to Might, "Warren Spahn," "Dr. Dre," and "In the bay."15 The whimsical humor is even more prevalent in

\footnotetext{
12 Brett Leveridge, “Men My Mother Dated,” Might Magazine, February/March 1996, 11.

${ }^{13}$ Paul Bennett, "We are in a State of Oklahoma," Might Magazine, February/March 1996, 10.

${ }^{14}$ Dave Eggers, “Copyright Page,” Timothy McSweeney's Quarterly Concern, Autumn 1998.

15 “Rhyme Time!” Might Magazine, February/March 1996, 10.
} 
McSweeney's. On that same copyright page of the first issue Eggers notes that they are "published quarterly by the Arena Football Marketing Corporation of North America."16 Still, despite the many similarities between Might and McSweeney's, there are some important differences as well. First, the content of the two magazines is quite different. From the beginning, McSweeney's has been a literary magazine, focused on publishing fiction, while also publishing some non-fiction essays. Might, on the other hand, did not publish fiction regularly and was more concerned with a certain way of living, as Dave Eggers explains in A Heartbreaking Work of Staggering Genius: “All we really want is for no one to have a boring life, to be impressive, so we can be impressed. We try to convince people we're a lifestyle magazine. 'See, we're talking here about a style of life.... Get it? Not lifestyle like lifestyle. Life. Style. A style of life." "17 With that idea guiding the magazine, Might covered topics like local TV news and weddings, albeit in a satirical fashion. These are topics for which McSweeney's has no interest. When Might did publish fiction, however, it often featured established fiction writers like David Foster Wallace and William T. Vollmann, both of whom would later appear in McSweeney's as well.

The magazines also differ in terms of circulation and advertising. McSweeney's has always had small circulation numbers and no advertisements. Instead, it has relied on subscriptions and a high cost per issue to keep the magazine successful. In contrast, Might had quite large circulation numbers and advertisements from major corporations in each issue. In issue ten alone, there are advertisements from Vans, Goldschlager, and

\footnotetext{
16 Eggers, “Copyright Page," Autumn 1998.

${ }^{17}$ Eggers, A Heartbreaking Work, 175.
} 
Vibrance hair products as well as a number of smaller companies. The difference in circulation numbers and advertising revenue is something that Eggers clearly believes led to the failure of Might and to the success of McSweeney's and its sister publication The Believer. In an interview with Nina Siegal for The Progressive, Eggers spoke candidly about these differences:

I also prefer to work on a small scale. With Might, we did it the dumb way. We thought we had to do 100,000 circulation and we had to have all this advertising, and it was never going to happen and no one got paid, we were all perpetually disappointed, and it folded. We found out that wasn't the way to do it. With McSweeney's and The Believer we decided to do the math better, to depend on the readers, not on advertisers or anyone else. If the readers think it's good, it will keep growing. That way, there's no compromise. The Believer has a circulation of 17,000 to 20,000 and I don't know if it will ever surpass that. And get this: Because of reader support, McSweeney's, the literary quarterly, is able to subsidize some of the more eccentric projects we take on. It's bizarre but it can work if you depend on the wisdom of your readers. ${ }^{18}$

Although Might would only have a three-and-a-half-year run before its end, it was clearly an important magazine — not only for allowing Eggers to develop a voice that would carry over in some ways to McSweeney's, but also parodoxically because it was unsuccessful. The failure of Might forced Eggers to reevaluate his ideas about how to run

18 Nina Siegal, "Dave Eggers," The Progressive, November 2007, 36. 
a magazine, which, in many ways, led him to a plan that has been copied by many other successful little magazines.

After Might folded, Eggers worked briefly as an editor for Esquire. He quickly became disillusioned with what he would refer to as "the mass market." 19 In the same interview with Siegal, he went on to explain his feelings further: "I don't know how to explain it. Everyone has a different comfort level with the mass market, and I guess I hit my limit." ${ }^{20}$ He would leave Esquire to begin work on his memoir.

During the writing of the memoir, however, Eggers began working on two different magazines. One of them would become McSweeney's, which began "on his kitchen table in an act of procrastination." ${ }^{21}$ In an interesting but puzzling move, the other magazine would lead Eggers back to the mass market from which he had just left. In 1998, the same year that the first issue of McSweeney's was released, Eggers took a job as a "part-time writer and sort-of consultant""22 at the then-fledgling ESPN The Magazine. He would eventually leave to "write books and do other stuff,",23 but he had clearly discovered that the mass market wasn't entirely bad. He would eventually return to its domain in the form of screenwriter more than a decade later with screenplays for the films Away We Go and Where the Wild Things Are.

\footnotetext{
${ }^{19}$ Ibid.

${ }^{20}$ Ibid.

21 D’Arcy Doran, “Beyond The Lattice,” Huck, April/May 2013, 24.

22 Dave Eggers, “Making It Up As We Go Along,” ESPN.go.com, http://sports.espn.go.com/espnmag/story?id=3288256.

${ }^{23}$ Ibid.
} 
While the move was puzzling considering Eggers' comments about his time at Esquire, the move back to the mass market made perfect sense when placed into the context of the history of the little magazines. As Scholes and Wulfman researched the history of the little magazines, they discovered that it was difficult to determine whether a magazine was entirely little or entirely part of the mass market: "When we look into the matter, neither the little magazines of [the Modernist] period nor the large ones were purely and simply 'little' or 'large.' And though they were all modern, they were not all equally or consistently modernist. ${ }^{, 24}$ Likewise, McSweeney's and the magazines of The McSweeney's Group cannot be labeled purely little or large. Even though the magazines have more in common with a little magazine, each still possesses aspects of a large magazine. If, as I will contend, McSweeney's is the model for this second golden generation of little magazines and Dave Eggers is the primary actant behind the group's formation, the presence of these mass-market influences on The McSweeney's Group can be traced back to Eggers' time working at magazines like Esquire and ESPN The Magazine.

${ }^{24}$ Scholes and Wulfman, Modernism in the Magazines, 32. 


\section{MCSWEENEY'S PROVIDES THE MODEL}

\section{i. The McSweeney's Design Aesthetic}

When McSweeney's first issue appeared in 1998, it did not resemble many of the literary magazines active during that time. Its contemporaries at the time were primarily either institutionalized literary magazines like The Kenyon Review, The Yale Review, and The Georgia Review, or longstanding literary magazines like The New Yorker and Harper's. McSweeney's rejected the high-toned pretentiousness of these established journals and, particularly in its first issue, actively satirized them. As Caroline D. Hamilton notes, “As much as it was a literary journal McSweeney's was also a parody of literary journals. McSweeney's made it clear from the outset that it refused to take the world of letters seriously, or at the very least, would take letters seriously only in so far as they had anything to do with typography and bookish graphic design." 25 While I do not agree with Hamilton's assertion that McSweeney's would not take the world of letters seriously, I do agree that McSweeney's was actively parodying, especially in its first issue, these types of established literary magazines.

McSweeney's also rejected the shift of literary magazines from print to entirely digital platforms. Although some of its contemporaries transitioned from print magazines to entirely digital magazines, others like The New Inquiry and Guernica have been online publications since inception. While rejecting the trend of literary magazines becoming entirely digitalized, McSweeney's was conscious of the value of developing a digital presence as a means to draw readers to its print magazine. It is my assertion that

\footnotetext{
${ }^{25}$ Caroline D. Hamilton, One Man Zeitgeist: Dave Eggers, Publishing and Publicity (New York and London: Continuum, 2010), 12.
} 
McSweeney's recognized that literary magazines did not have to choose between entirely digital or entirely print publications. Rather, McSweeney's saw that a digital platform could supplement subscription to its magazine by publishing short, popular humor pieces, which enticed readers to purchase the longer content found in its print magazine. By choosing definitively to have a print magazine, McSweeney's neglected to follow the paradigm of contemporary magazines. ${ }^{26}$

If McSweeney's first issue did not have much in common with its contemporaries, its closest relative was a brief and little-known modernist little magazine called Le Petit Journal des Refusees, edited by Gelett Burgess in San Francisco in 1896. Le Petit Journal des Refusees claimed only to publish pieces rejected from other magazines, just as the first issue of McSweeney's would claim to do: “McSweeney's began in 1998 as a literary journal that published only works rejected by other magazines." ${ }^{27}$ McSweeney's also shared Le Petit Journal des Refusees' affinity for "nonsensical...inside jokes"28 as well as eccentric design elements that emphasized the use of text in places where it was not normally seen.

Unlike McSweeney's, however, Le Petit Journal des Refusees was never meant to continue past its initial issue, and, largely for this reason, critics like Brad Evans have struggled with how to categorize it in relation to other modernist little magazines:

\footnotetext{
${ }^{26}$ See page 41 herein for further explanation.

27 “'Timothy McSweeney’s Quarterly Concern,” McSweeney’s Quarterly \& Books, n.d., http://www.mcsweeneys.net/books\#about.

28 Brad Evans, "Introduction to Le Petit Journal des Refusees," Modernist Journals Project, Brown University, 2, http://dl.lib.brown.edu/mjp/render.php?id=mjp.2005.00.119\&view=mjp_object.
} 
In distinguishing its type, it is worth noting that, unlike most magazines, the cultural influence of this one can neither be judged by the longevity of its print run, nor by the breadth of its circulation statistics, nor by the reputation of its contributors. It was not a distribution mechanism for works of art, literature, opinion and news; but rather, it was an aesthetic and comedic end in itself.... We could call it a self-contained objet d'art (semi-mass produced), if one lacking in the pretentions normally associated with such things. It is in part because of its classificatory oddity that I've adopted the practice of an early bibliographer... who in 1903 gathered them under the title "ephemeral bibelots" — transitory little art book-things. ${ }^{29}$

Had McSweeney's lasted for only an initial issue, it too would have likely been considered an "ephemeral bibelot" and been unable to have the impact it has had on contemporary little magazines. Though there is a greater number of authors featured in the first issue than there are in Le Petit Journal des Refusees, including a major one in David Foster Wallace, the issue was put together almost entirely by Eggers with work from a close network of friends, some of whom he had worked with at Might. It also would have likely been remembered for being a comedic end in itself.

The purpose of the comparison with Le Petit Journal des Refusees is not to link McSweeney's to the first golden age of the little magazine, nor is it to show, for lack of a better term, its oldest surviving relative. After its initial issue, McSweeney's is more

${ }^{29}$ Ibid., 4. 
closely linked to the first golden age through modernist little magazines like Burgess' own The Lark and also The Dial, ${ }^{30}$ either of which might also be seen as a more apt forefather than Le Petit Journal des Refusees. Rather, the purpose of the comparison is to show why, after its initial issue, McSweeney's was forced to change in a small, but crucial way, if it desired to be anything more than an "ephemeral bibelot." Though it would still value humor and eccentric design beginning with the second issue, McSweeney's published pieces specifically intended by their authors to be published in $M c S w e e n e y$ 's. McSweeney's decision, though it could be interpreted as insignificant, would be an important factor in leading to the establishment of a model that the subsequent little magazines would follow. The transition from a humorous parody of literary magazines to a more serious-minded literary magazine that frequently featured humor would help McSweeney's reach a wider audience outside of Eggers' circle of friends as well as allow the journal to be taken more seriously by those who read it.

After its initial issue, the importance of McSweeney's as a model for future magazines can be broken down into three primary strategies: its overall aesthetic, its business model, and Eggers' editorial role. Albeit for different reasons, each of these strategies as displayed in McSweeney's has proven invaluable for other little magazines, as either a model to follow or to position themselves against. Although someparticularly $n+1$ - have chosen to position themselves against McSweeney's prevailing aesthetic, all have followed McSweeney's business model. However, no little magazine operating today has seen a single editor fill the role of the ideal editor, as Philpotts defined it, as Eggers has done for McSweeney's. Rather, it has taken a team to recreate

\footnotetext{
${ }^{30}$ Lorraine Adams, "The Write Stuff," The American Prospect, February 2003, 41.
} 
his gifts as an editor, which I contend is significant because McSweeney's could not have been as influential as it has been without Eggers at its helm. Finally, and perhaps most surprisingly, Eggers and McSweeney's never attempted to keep any of these trade secrets to themselves. As soon as, and even before, they were successful with them, they published how much they were spending and what they spent it on, which gave other little magazines access to the business model.

Of the three, what McSweeney's is most critically lauded for is its aesthetic. Superficially, its aesthetic influence upon the second generation of little magazines is the most obvious and most likely the reason that nearly every critical discussion of McSweeney's has centered on the aesthetics of the magazine. However, there are two distinct parts of the McSweeney's aesthetic, which are often grouped together: its design aesthetic and its literary aesthetic. Although they combine to form what is commonly referred to as the McSweeney's style, it is worthwhile to trace how each developed separately before discussing them together.

It is my contention that the McSweeney's design aesthetic is a mixture of styles both past and present with an emphasis on text created by often obscure printing methods in an attempt to distance itself from contemporary aesthetics of digital printing culture. Although critics like Hamilton have noted parts of this aesthetic, the major misconception of the McSweeney's design aesthetic is that it was created entirely by McSweeney's or entirely by Eggers. By using ANT and tracing the many actants involved in creating the design aesthetic, I will not only prove my analysis to be correct, but also show why the focus on a particular actant is problematic in trying to determine the creation of the McSweeney's aesthetic. 
To begin tracing McSweeney's design aesthetic, it is appropriate to begin with the primary actant, editor Dave Eggers. ${ }^{31}$ On McSweeney's masthead, Eggers' role is frequently listed as "EDITING/DESIGNING: Dave Eggers,",32 which is the initial indicator that Eggers is heavily involved in the design elements of the magazine. In addition, as not only the magazine's editor but also its publisher, it is clear that Eggers has the most control over McSweeney's and its design.

With that noted, the first (traceable) actant to have an influence on Eggers and the McSweeney's design aesthetic is the Oddi Printing Company, located in Iceland. Iceland seems like a bizarre place to print an American magazine, but according to Eggers there were reasons for this decision. In an article in Print, Eggers explains his decision to Todd Pruzan:

Why Iceland? The main reason McSweeney's originally approached Oddi Printing in 1998 was because it was located in Iceland. I thought the novelty of printing in Iceland would be a good excuse to go there.... It came in competitive with the other printers I'd approached, and that was all I needed as an excuse to go with Oddi. ${ }^{33}$

The whimsicality found in the above story fits with the McSweeney's overall aesthetic, but there were other qualities that Oddi presented, besides its location, that Eggers valued

\footnotetext{
${ }^{31}$ Although other actants like Might and ESPN The Magazine may have influenced the McSweeney's design aesthetic, there is no traceable documentation to directly show their influence. Therefore, they do not form a significant part of the network that I am examining.

32 Dave Eggers, “Copyright Page,” Timothy McSweeney’s Quarterly Concern, Late Winter/Early Spring 1999.

33 Todd Pruzan, “Oddi Jobs,” Print 60, no. 3 (2010): 90.
} 
as well. One of these qualities was the people who worked for Oddi, two of whom would become important actants as well. These two men were "Arni Sigurdsson, who was the New Jersey-based American rep...[and] Bjossi Viosson, the project manager in Reykjavik," ${ }^{34}$ both of whom would become heavily involved in the design process. Sigurdsson and Viosson were Eggers' primary contacts at Oddi and would inform Eggers about the costs and timeframe of completing whatever new design Eggers and McSweeney's had in mind.

Another quality that Eggers valued was Oddi's willingness to attempt new projects: "We were pretty determined that each issue of the magazine look different than the one before it.... A lot of printers will roll their eyes... and complain that the project extends beyond their normal boundaries, but the Oddi staff were always hoping we'd do something unusual." ${ }^{35}$ Here, then, is one of the first components of McSweeney's design aesthetic: Each issue of the magazine would be presented differently than the one before it. While the initial idea for this approach can be traced to Eggers, its execution can also be traced to Oddi and its staff since, without their creative input and support, Eggers and McSweeney's may never have had the opportunity to create a different design for each issue.

Continuing to trace this section of the network through Oddi, another actant comes into focus: printing techniques of the past. With Oddi, McSweeney's was "resurrecting printing techniques that hadn't been used in a while: die-cuts, elaborate foil

\footnotetext{
34 Ibid., 90.

35 Ibid., 90-91.
} 
stamps, ribbon markers, endpaper printing, ${ }^{96}$ as a way to create a different element for each issue. As an actant, though, the printing techniques of the past not only contributed to McSweeney's design aesthetic by allowing them to experiment in the creation of a new design for each issue but they also allowed McSweeney's to consciously reject the newly rising aesthetic presented by digital publication. As Eggers notes on the copyright page of McSweeney's five (Summer 2000), the first issue of McSweeney's to appear as a hardcover, this rejection of new publishing methods was another crucial part of their design aesthetic:

When everyone is talking about electronic books... and about books on demand... and about the future of books and all, we think the direction we should be going in is obvious, and is in some ways the opposite of the way most people are talking about going. Our theory holds that a) People like hardcover books. They like them because they are good to look at, and are permanent, and are decorative, and can be given as gifts, and kept until one dies. ${ }^{37}$

At this point, tracing the involved actants has proven part of my contention. One aspect of the McSweeney's design aesthetic is the use of old-fashioned printing techniques and the rejection of digital publishing. In addition, by tracing the design section of the network, I have demonstrated that other actants beside Eggers and McSweeney's have also played a crucial role in developing the McSweeney's design aesthetic.

\footnotetext{
${ }^{36}$ Ibid., 91.

${ }^{37}$ Dave Eggers, “Copyright Page,” Timothy McSweeney’s Quarterly Concern, Summer 2000.
} 
The old-fashioned printing techniques and the rejection of new methods of printing lead us to yet another actant influencing the design section of the network, which is the eclectic pastiche of McSweeney's. Lance Knobel discusses the pastiche in the article, “The Little Journal That Grew Big." As Knobel notes of McSweeney's design, "The inspiration is found in old books, pulp magazines, advertising fliers, MAD...halfforgotten literary journals and a host of other references. ${ }^{38}$ Similarly, in that same article, Pruzan discusses the beginning of McSweeney's, where he worked from 1998 to 2000: "Here we are...looking for all the world like a hilariously melancholy medical journal from the age of phrenology and typhoid. Dave Eggers was 28 at the time. I was, too, and guys that age really have no business knowing how to channel the nineteenth century. ${ }^{.39}$ The ability to reference, reframe, and reuse eclectic sources, from $19^{\text {th }}$ century medical journals and literary magazines to more contemporary references like MAD Magazine, is the final major component of the McSweeney's design aesthetic.

As I have indicated through tracing the actants that have influenced McSweeney's design aesthetic, McSweeney's design is a mixture of styles both past and present, with an emphasis on text created by often obscure printing methods in an attempt to distance itself from contemporary aesthetics of digital printing culture (see Figure 1). In Knobel's article he quotes an email from Eggers describing his plans for McSweeney's, "This thing will be about trying new, and almost certainly misguided, ideas." ${ }^{, 40}$ What is most interesting about this comment is that, at least in regard to design, McSweeney's is

\footnotetext{
${ }^{38}$ Lance Knobel, “The Little Journal That Grew Big,” Eye, Winter 2010, 32.

${ }^{39}$ Ibid., 30.

${ }^{40}$ Ibid., 32.
} 
not trying anything "new," in the sense of "new" as "original." Rather, McSweeney's design creates something "new" from styles and techniques that are outdated and out-offashion. This line of thinking follows in the tradition of Ezra Pound, whom, according to Scholes and Wulfman, must be recognized "as a founder or progenitor of modernist periodical studies."41 Pound's study of periodicals and work with them was not limited to modernist magazines alone. Rather, he was profoundly influenced by the wider existing periodical culture of his era. It is this same understanding and value in all magazines that Eggers and McSweeney's share with Pound.

Knobel also helps us understand the lasting influence of McSweeney's design aesthetic on the second generation of little magazines. He notes, “McSweeney's was hardly the first iconoclastic literary journal but it may well have been the first with such an acute design awareness." 42 The "acute design awareness" is also an understanding that in order to compete with (often free) digital literary magazines and other digital media, print media must provide something that digital media cannot provide. For $M c S w e e n e y$ 's, the idea would be not to only provide quality literary content, but also to attract consumers by presenting that content in the form of an engaging art object, something which digital media cannot replicate. As I have shown previously, however, McSweeney's did not ignore digital media entirely. Rather, McSweeney's used shorter digital content to attract readers to its print magazine. Still, McSweeney's attention to design is more than just an aesthetic concern; it is also a means for McSweeney's to

\footnotetext{
${ }^{41}$ Scholes and Wulfman, Modernism in the Magazines, 6.

${ }^{42}$ Knobel, "Little Journal," 32.
} 
separate and distinguish itself from the trend of exclusively digital media growing around McSweeney's. 


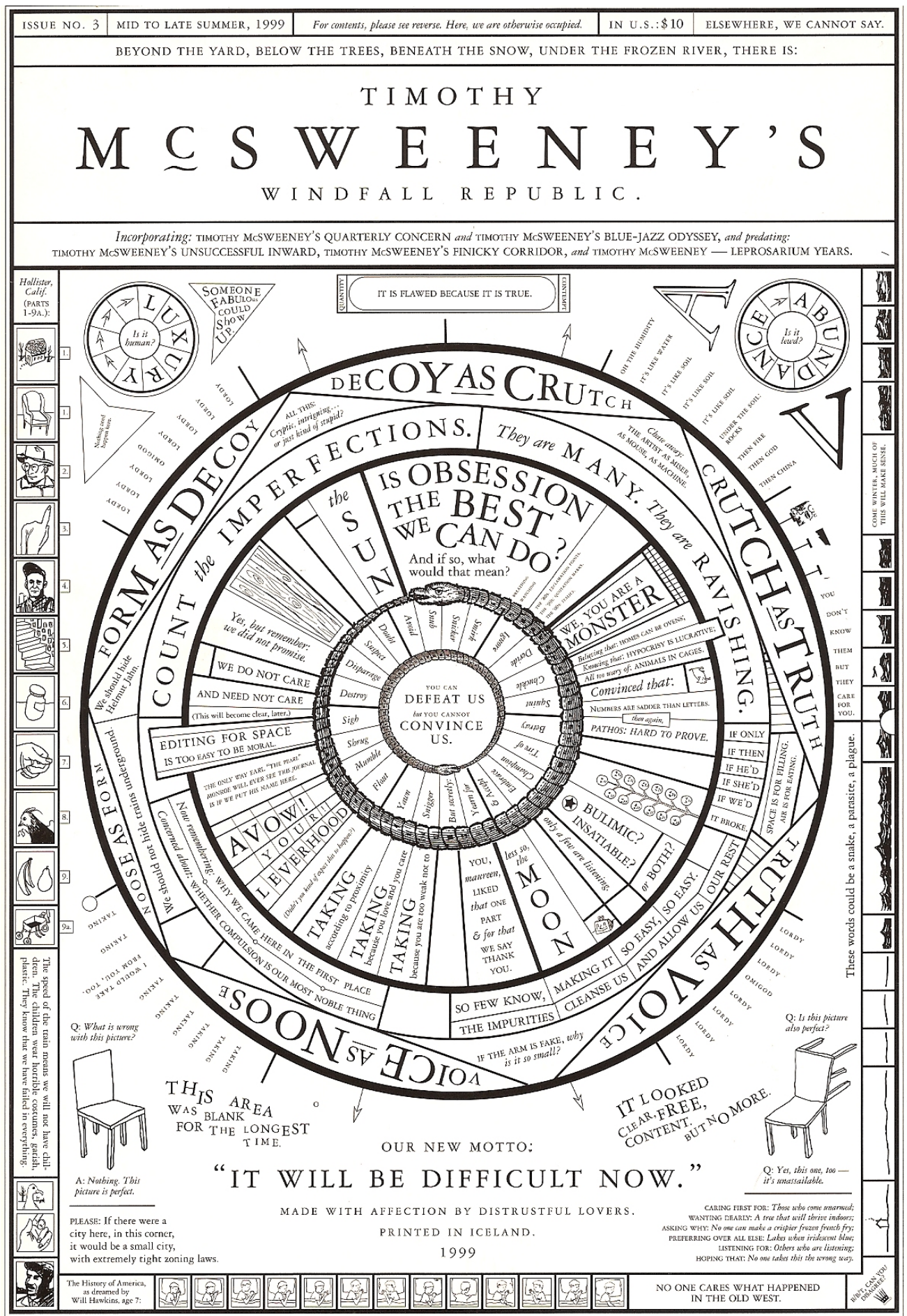

Figure 1: Cover of McSweeney's Issue Three, Late Summer, Early Fall 1999 
Though few little magazines have attempted to replicate McSweeney's commitment to making each issue almost entirely different, the little magazines within the McSweeney's group and even many of those outside it have developed this "acute design awareness," on the basis of the example displayed by McSweeney's. Specific examples will be addressed further along, but, for now, the importance of McSweeney's design aesthetic is that it showed the little magazines that emerged in its wake that design is an important tool in competing with the ever-growing presence of and competition from digital media.

\section{ii. The McSweeney's Literary Aesthetic}

The second component of McSweeney's overall aesthetic is its literary aesthetic. My contention is that the McSweeney's literary aesthetic, both in its fiction and nonfiction, is eclectic in subject matter with a penchant for absurdist humor, while at the same time clearly placing value in empathy. As an additional component of its literary aesthetic, McSweeney's values experimentation, specifically in the ability of authors to experiment with their work. However, I will also argue that while McSweeney's has an influential literary aesthetic, it is strongly supplemented by its design aesthetic. In other words, McSweeney's design aesthetic has helped create the freedom necessary for its frequent experimentation in terms of its literary content, something that critics have failed to account for.

During the two-year period examined here, McSweeney's essentially only published short fiction, creative non-fiction, and a minimal number of essays. Of course, the fiction appeared in different formats and some of the essays that appeared to be non- 
fiction blended fiction and non-fiction, but, as a means of categorization, these were the major three genres. McSweeney's also made the conscious decision to leave out standard parts of the average literary journal, namely poetry and literary criticism.

While ANT is useful in tracing the absence of criticism, it fails to help discover any significant reason for why McSweeney's does not publish poetry because of a lack of traceable documents. On the "Guidelines for Quarterly Submissions" page on the McSweeney's website, a guideline reads: "POETRY can be wonderful, but is not something we publish," ${ }^{43}$ but no further explanation is given as to why that might be. If there is a specific reason that $M c$ Sweeney's and Eggers decided to refrain from publishing poetry during the early years, that reason has not been revealed in any interview given by Eggers or in any writing he has published. However, in issue twenty-two (February 2007), McSweeney's broke its own rule and published poetry for the first time.

Although there is no detailed explanation for the absence of poetry, there is a reason given for the omission of criticism. Using ANT, we can trace that decision to Eggers, who spoke about the topic in an email interview with the Harvard Advocate. In the interview Eggers writes a lengthy response to one of the questions that addresses the idea of "selling out," but gives an insight into why McSweeney's does not include criticism of any kind: "Do not be critics, you people, I beg you. I was a critic and I wish I could take it all back because it came from a smelly and ignorant place in me, and spoke with a voice that was all rage and envy. Do not dismiss a book until you have written

\footnotetext{
43 "Guidelines for Quarterly Submissions," McSweeney's Internet Tendency, n.d., http://www.mcsweeneys.net/pages/guidelines-for-quarterly-submissions.
} 
one, and do not dismiss a movie until you have made one." ${ }^{, 44}$ Eggers makes a choice to distance himself from contemporary forms of criticism, a distancing that would be later discussed and elaborated on by Heidi Julavits in the initial issue of The Believer. Therefore, the decision not to include critical articles or book reviews is a conscious one made by Eggers as editor. The decision is also important because it separates McSweeney's in a substantial way from most literary journals that have come before it. Without the standard book review or critical article, McSweeney's has put the focus of their journal on the artist and the art, placing the importance on the act of creation and not the act of criticism.

If we continue to trace Eggers' comments that he has given about McSweeney's in interviews, we can get a strong sense of what he intended McSweeney's literary aesthetic to be. In the same interview with the Harvard Advocate he writes:

My favorite pieces [in McSweeny's] were all written by Paul Collins. His series, which chronicles the lives of various hopeless dreamers of the nineteenth century, will soon be a book.... It's the closest stuff to what I wanted McSweeney's to be about.... We care about doing what we want to do creatively. We want to be interested in it. We want it to challenge us. We want it to be difficult. ${ }^{45}$

From these comments, it is clear that one component of McSweeney's literary aesthetic is experimentation. Eggers' comments about Collins' work reveal an affinity for

\footnotetext{
${ }^{44}$ Saadi Soudavar, “An Interview With Dave Eggers,” Armchairnews.com, April 28, 2000, http://www.armchairnews.com/freelance/eggers.html.

${ }^{45}$ Ibid.
} 
experimentation because of the difficult challenge that it presents. The theme of a hopeless dreamer willing to experiment with something difficult and challenging seems to be exactly what Eggers would like McSweeney's to emulate. If Eggers' comments were about the genre Collins works in, there would be much more non-fiction that contained creative components throughout McSweeney's initial issues, but fiction far outweighs that type of work. However, the genre used for that work is inconsequential for McSweeney's; McSweeney's finds importance in the process behind the work rather than how the work is classified.

In a recently published article about Eggers, the McSweeney's publishing house, and Eggers' tutoring center 826 Valencia, literary scholar Amy Hungerford discusses Eggers' aims when he created McSweeney's. Hungerford notes that "In McSweeney's, Eggers creates a context in which others can also exercise some degree of freedom." ${ }^{\natural 6}$ The term "freedom" gives the sense that the contributors for McSweeney's are not supposed to fit into a certain style that McSweeney's has created, but rather are allowed to, again, produce writing that interests and challenges them. Eggers echoes Hungerford's comments when he states, "the m.o. here is really to let writers be, to fool around a little, take a chance. ${ }^{47}$ Again, there is a sense given by Eggers that the McSweeney's literary aesthetic is not created as much by the editor as it is by the writers who submit work to the magazine.

\footnotetext{
${ }^{46}$ Amy Hungerford, "McSweeney's and the School of Life," Contemporary Literature 53, no. 4 (2012): 656.

${ }^{47}$ Ibid., 657.
} 
What have the critical reactions been to the McSweeney's literary aesthetic? To begin, Knobel's article, which attempted to capture McSweeney's design aesthetic, also attempts to give a brief description of its literary aesthetic as well. He notes that after the first issue "the dominant style of McSweeney's writers was established: there is humor, with a touch of the absurd rather than fashionable snarkiness; descriptions are clear and almost deadpan, and sentiment is not sniffed at," and he continues, "McSweeney's, however, is nothing if not eclectic in its subjects and writing styles." ${ }^{48}$ Knobel's comments agree with Eggers' earlier statement about creating a space for writers to be able to experiment. Unfortunately, however, Knobel only offers general comments in relation to the McSweeney's literary aesthetic and does not analyze any specific short story or article, which would provide a better understanding of how the McSweeney's literary aesthetic is displayed in the fiction it publishes.

Just such an analysis, however, is offered by Judith Shulevitz in an article for the New York Times. She states that McSweeney's contains "funny and daring, if at times unbearably whimsical, fiction and essays and art." ${ }^{, 49}$ For Shulevitz, the literary aesthetic is second in importance to the design aesthetic: “The stories published in McSweeney's, though sometimes quite good, are secondary to the packaging, which is the central drama. ${ }^{50}$ In the end, the McSweeney's literary aesthetic fails for Shulevitz not because it isn't original or valuable, but because it has been adopted by the mainstream culture. Its

\footnotetext{
${ }^{48}$ Knobel, "Little Journal,” 30.

49 Judith Shulevitz, "Too Cool for Words," The New York Times, May 6, 2001, http://www.nytimes.com/books/01/05/06/bookend/bookend.html.

${ }^{50}$ Ibid.
} 
own success has paradoxically devalued the magazine because it "has lost its power to critique."

The strongest critical assessment of McSweeney's literary aesthetic_-and also the closest resembling a scholarly critique - emerges in an article by Ruth Franklin. Writingf for Slate, Franklin analyzes what she labels the "McSweeney's short story," something that she sees as "an entirely new phenomenon." $" 52$ For Franklin, this new type of story is "younger and hipper and more experimental, but no less influential" than its older sibling the "New Yorker short story," which she describes as "the contemporary, quotidian, plotless, moment-of-truth revelatory story" ${ }^{, 53}$ by the novelist Michael Chabon, whom Franklin quotes in her article. Though Franklin sees the McSweeney's short story as influential, she believes it lacking “in one of literature's most essential qualities: the ability to amaze."54 In her analysis, although the McSweeney's story shares qualities with the New Yorker short story, namely that it is "contemporary, it's often quotidian, it's certainly plotless," it fails because "it substitutes nihilism for epiphany." 55

Unlike the articles of Knobel and Shulevitz, Franklin identifies a specific and paradigmatic example of the McSweeney's short story, Ken Foster's “Red Dresses," which was published in issue three (Late Summer, Early Fall 1999). Franklin states that,

${ }^{51}$ Ibid.

52 Ruth Franklin, “The 98-Pound Gorilla in the Room," Slate, April 3, 2003, http://www.slate.com/articles/arts/culturebox/2003/04/the 98pound_gorilla in the room.html.

${ }^{53}$ Ibid.

${ }^{54}$ Ibid.

${ }^{55}$ Ibid. 
"the story itself meanders randomly, with dramatic shifts in tone that defy explanation. Foster is clearly trying to create a sense of disequilibrium in the reader, but he does so at the cost of sense." letter office of a hipster writer's dream zine—a repository for witty letters, articles and other random...musings that could find their way into print nowhere else" into "a literary journal, not a collection of castoffs," but she incorrectly identifies the change as taking place between issues two (Late Winter, Early Spring 1999) and three. The decision had already taken place between issues one and two. With this change, Franklin also sees a tone shift from "self-aggrandizement disguised as self-effacement" with a penchant for humor to a more nihilistic tone that still retained some humor, although one assumes Franklin is suggesting a type of black humor instead of a self-effacing humor. As a result, she sees value in McSweeney's as a "counterpoint to the mainstream publishing scene" and as "the first bona fide literary movement in decades," but she believes the "quality of the work inside McSweeney's has yet to live up to the promise of the magazine's gloriously designed packaging. ${ }^{, 57}$ Franklin's contention, especially the final part, is important because it points to a relationship between the packaging and the content, something other critics have failed to establish a direct connection between.

To assess the validity of these critical assessments, particularly those of Franklin, it is valuable to examine Foster's "Red Dresses" from issue three. As far as Foster's narrative is concerned, there is not anything particularly experimental about "Red

\footnotetext{
${ }^{56}$ Ibid.

${ }^{57}$ Ibid.
} 
Dresses." The story is told in a first person narrative and proceeds in a linear fashion, except for a brief flashback. Franklin claims that the McSweeney's short story is often "quotidian" and that Foster's story has "dramatic shifts in tone that defy explanation,"58 which keeps the story from making sense, but her reading of this particular story is problematic. The story focuses on a man whose wife has recently left their marriage. The man attends a party where everyone in attendance must wear a red dress, hardly an everyday occurrence. Similarly, there are not any dramatic shifts in tone; the narrator is continually depressed and uncomfortable throughout the story, especially during the flashback scene where he considers suicide. Although Franklin claims the McSweeney's short story lacks epiphanic moments, as the narrator walks home from the party, he states, "Light caught in the fog, an orange glowing haze formed over the city, the wind picked up the leaves around me, and I thought, this feels good somehow: to be alive., ${ }^{59}$ In this moment, he has realized again that it is good to be alive; he has had a moment of insight. Franklin's shortsighted criticism of Foster's story fails to recognize this moment as an epiphany.

Furthermore, her reading is not entirely inaccurate because experimentation does take place, only it occurs in the layout of the story and not within the narrative itself. McSweeney's has a writer named Ana Marie Cox pose as an academic to comment on Foster's "Red Dresses" in the margins of the story. Cox's commentary mimics the type of criticism done by academics and its inclusion makes sense based on Eggers' earlier

\footnotetext{
${ }^{58}$ Ibid.

${ }^{59}$ Ken Foster, “Red Dresses," Timothy McSweeney's Quarterly Concern, Late Summer/Early Fall 1999, 133.
} 
statements about his aversion toward criticism and its lack of appearance anywhere else in McSweeney's. Unlike most literary magazines where the critics have the last word, McSweeney's allows Foster to offer critical responses to Cox's faux-academic criticism, giving the author the final say on the story. So while experimentation happens in "Red Dresses," it is happening in the format of the story and fits perfectly with everything McSweeney's and Eggers seem to champion.

Of the three critical analyses I summarized above, Knobel's assessment of the literary aesthetic of McSweeney's is both most in agreement with and supportive of my own argument that McSweeney's literary aesthetic is eclectic in subject matter with a penchant for absurdist humor, while at the same time clearly placing value in empathy. However, if, as I contend, a crucial aspect of the McSweeney's literary aesthetic is that the author is allowed to experiment in whatever way he or she might desire, then it seems perplexing that many critics have separated the design aesthetic from the literary aesthetic in their analyses. For example, in Foster's "Red Dresses," Foster experiments with the idea of the writer being allowed to respond to the critical assessment of his work. However, Foster can only experiment in this fashion because the design of the story within McSweeney's allows him to do so by creating space in the sidebar for the discussion to take place.

Therefore, while I do not agree with Shulevitz's claim that McSweeney's popularity has lessened its significance, I find her claim that McSweeney's "central drama" is the packaging rather than the content to be a valuable one. By attempting to understand the relationship between the design aesthetic and the literary aesthetic, Shulevitz is not only one of the few critics to take this important step, but also makes a 
connection to my own argument. However, I still disagree with Shulevitz's assessment that the packaging is the "central drama" rather than the content. In actuality, the "packaging," as she refers to the design, actually creates new ways for the authors to experiment; the design actually supplements the literary aesthetic, rather than supplants it.

Foster's story has already provided one example of the design as supportive of an author's attempts at experimentation. In issue three, David Foster Wallace's story “Another Example of the Porousness of Certain Borders (VI): Projected But Not Improbable Transcript of Author's Parents' Marriage's End, 1971" provides an additional experimental story that is supported by the design. Foster Wallace's "Another Example" is a brief conversation between a husband and wife who have suddenly decided to divorce. Although the pithy dialogue in the story is at times humorous, the story attempts to capture a brief and life changing moment for the "author," i.e., the exact moment his parents decided to divorce. Since the story attempts to capture such an ephemeral moment, it is extremely short; only 136 words make up the entire story. Most magazines would find a story like this challenging to publish due to its brevity and use of nothing but dialogue, which would likely leave a lot of empty space on the page it is published, something that magazines are hesitant to do. However, McSweeney's design aesthetic, particularly in this case $M c$ Sweeney's fondness for placing text in places that the reader might not expect, supports Foster Wallace's story by publishing it on the spine of issue three. Whereas this experimental story might have been hard to publish in another magazine, McSweeney's is able to publish it because of both its literary and design aesthetics. With these stories, it is clear that the "packaging" is not the central drama as 
Shulevitz claims. Rather the central drama is the interplay between the design elements and the content.

Shulevitz's point that the McSweeney's style has entered the popular culture does, however, help us in understanding the true influence of the McSweeney's literary aesthetic on the second generation of little magazines. Unlike the McSweeney's design aesthetic, other little magazines have not adopted that component directly per se. Though some magazines like The Believer have taken aspects of the literary aesthetic and others like $n+1$ have clearly positioned themselves against it, no magazine has adopted it completely. The lack of a complete adoption of the model is to be expected, as no little magazine could find success if it simply copied everything that McSweeney's had become known for. Instead, the literary aesthetic has had an indirect influence on these other little magazines, by influencing a developing consumer market for little magazines, which in turn would support them.

Lorraine Adams noted this influence by observing the growing movement developing around McSweeney's. As she attended a book reading by Eggers she noticed that:

Eggers' literary superstardom is prompting an alternative culture that has grown up around him over the last five years. It is a San Francisco- and Brooklyn-based community of writers, artists, designers...with a growing national following. They are the readers, contributors and designers of the literary journal...McSweeney's... They are idealistic about 
education....and impatient with the homogenous culture that corporations produce. ${ }^{60}$

She subsequently compares this McSweeney's movement to similar movements, including the London counterculture of the early 1960s, the 1950s Beat movement, which included the short-lived City Lights Journal, and the early days of the Dial, when it was a transcendentalist magazine edited by Ralph Waldo Emerson and Margaret Fuller. Though Adams was unsure at the time of the writing of her article in 2003 if McSweeney's would make the cultural impact that those other movements made, it almost certainly has.

It has made an impact largely because, as Shulevitz noted, it has become part of the mainstream culture. In fact, its impact has been deemed important enough to be examined by mass media outlets, something few little magazines have accomplished. As an example of this mass media coverage, Michael Wolff, writing for New York Magazine, notes, “[McSweeney's has] taken their media destinies into their own hands...and, along the way, [created] a fervent community of co-generationists and like-minded souls. ${ }^{, 61}$ In addition, even though Franklin is highly critical of the literary aesthetic of McSweeney's in her piece for Slate, she consents, "Regardless of whether self-referential play is to your taste, it's the first bona fide literary movement in decades." ${ }^{202}$ Discussion of McSweeney's has also appeared in The New York Times and the Wall Street Journal.

\footnotetext{
${ }^{60}$ Adams, "The Write Stuff," 39.

${ }^{61}$ Michael Wolff, “The Kidder King,” New York Magazine. http://nymag.com/nymetro/news/media/columns/medialife/4037/.

${ }^{62}$ Franklin, "98-Pound Gorilla."
} 
Its impact is not limited to the United States alone. In the British daily newspaper The Guardian, Stephanie Merritt writes that, "the obvious contemporary precedent for the resurgence of the small magazine is Dave Eggers's McSweeney's which in the Nineties became a beacon for writers weary of the limited possibilities of the mainstream press." ${ }^{63}$ Similarly, John Preston notes in The Telegraph that "[Eggers]...founded the most influential magazine in the United States, McSweeney's." ${ }^{\text {"64 }}$ McSweeney's has also seen coverage from The Economist as well.

Clearly, then, McSweeney's has had a strong cultural impact both in the United States and internationally through its design and literary aesthetics. However, these aesthetics have not simply affected the mass culture that has adopted it. Instead, they have affected a generation of writers as well, which critics have started to notice. In an article for The Guardian, Gordon Burn states, "It could be argued that...Eggers's influence on young writers coming out of the creative writing departments of the universities...is as pervasive as Raymond Carver's in the austere...1980s. ${ }^{, 65}$ Hungerford's piece on McSweeney's provides a specific example of this phenomenon in the writer Deb Olin Unferth. Hungerford notes that "Unferth identifies herself as having been something of a McSweeney's writer since before she published her first stories in the quarterly. As M.F.A. students...she and her classmates... 'all wanted to publish with

\footnotetext{
63 Stephanie Merritt, “A Bloomsbury set for the podcast age,” The Observer, March 31, 2007 , http://www.guardian.co.uk/media/2007/apr/01/pressandpublishing.books.

64 John Preston, "Dave Eggers interview: the heartbreak kid," The Telegraph, December 29, 2009 , http://www.telegraph.co.uk/culture/books/6865365/Dave-Eggers-interview-the-heartbreak-kid.html.

65 Gordon Burn, "The believers," The Guardian, March 26, 2004, http://www.guardian.co.uk/books/2004/mar/27/fiction.zadiesmith.
} 
McSweeney's." "66 The McSweeney's literary aesthetic provided a standard that many emerging writers wanted to emulate.

The literary aesthetic of McSweeney's has proved to be highly influential, though often indirectly, for this second generation of little magazines in two distinct ways. First, it has created a culture and movement that has sought out content produced by small magazines. In a sense, it has enlarged what was a small market seeking what little magazines offered. Second, the literary aesthetic influenced a significant number of emerging writers. Even if this second wave of little magazines was not consciously adopting McSweeny's literary aesthetic, they were often featuring a writer or, more likely, writers that had been significantly influenced by it.

iii. The McSweeney's Business Plan

The McSweeney's aesthetic is, arguably, the most influential aspect of the McSweeney's model. It has garnered the most recognition, praise, and criticism of any of the model's major components. However, the McSweeney's aesthetic would have been a short-lived and significantly less influential component had it not been for the McSweeney's business plan. Therefore, although the McSweeney's aesthetic is the most influential piece of the model, the McSweeney's business plan is certainly its most vital piece.

The influence of the McSweeney's business plan on the second generation of little magazines is twofold. Certainly, McSweeney's was not the first literary magazine to keep a detailed record of their costs and revenue. It was, however, the first little magazine to

${ }^{66}$ Hungerford, "School of Life," 663. 
publish a detailed account of their financial records and publishing practices for anyone to see and learn from, which is its first innovation. At a time when the prevailing belief was that publishing in print form was too expensive or too difficult and many literary magazines were increasingly available only digitally, $M c$ Sweeney's made it clear that the opposite was actually the case and that almost anyone could begin a little magazine. My contention is that the McSweeney's business plan's influence can be seen in the little magazines of The McSweeney's Group that have taken up the model and made it their own. From its first issue when it noted that, "This journal was typeset using a small group of fonts that you already have on your computer, with software you already own, ${ }^{, 67} M c$ Sweeney's inspired future little magazines to create a magazine in a print format as opposed to simply an online magazine and implied that anyone reading the magazine could start one of their own, using tools that were commonly at hand.

The second influential portion of the McSweeney's business plan on little magazines is its innovative use of digital media. Both in terms of using basic digital programs to create the print magazine and also creating a digital presence for their magazine, McSweeney's proved that a new little magazine does not have to choose one side or the other. Instead, digital and print media can be used to support each other and draw new readers to the print magazine that may have never been drawn in otherwise.

Once again, an appropriate place to begin to trace the business plan, which constitutes another element in "The McSweeney's Group" network, is with editor and designer Dave Eggers. As we have seen, Eggers is the driving force behind the McSweeney's aesthetic and it is clear from articles like Pruzan's “Oddi Jobs" that Eggers

\footnotetext{
${ }^{67}$ Eggers, “Copyright Page,” Autumn 1998.
} 
was acutely aware of the finances of the magazine, which displays his significant involvement in the creation of the business model as well. In addition, Eggers wrote the long, painstakingly-detailed accounts of the expense reports on the McSweeney's copyright pages, which will be soon analyzed further. With Eggers as our initial actant, we can trace the beginnings of what would become the McSweeney's business plan back to Eggers' role at Might. Might's primary importance to the business plan was that it failed to produce a sustainable model.

As Eggers stated, Might's comparatively large circulation numbers — about 100,000 per issue - and heavy reliance on advertising resulted in the failure of the magazine. It was not able to generate any profit or even to sustain itself. For McSweeney's, Eggers would need to find a different business plan or McSweeney's would undoubtedly end after a brief run just as Might had. With McSweeney's, Eggers created a different business plan that did not rely on ads and circulation numbers. Beginning with its initial issue, McSweeney's did not contain a single real advertisement (there were some faux advertisements that would appear in subsequent issues) until placing a single ad in issue five for a book that McSweeney's was publishing. In addition, McSweeney's initial circulation number was only 2,500 for its first issue. ${ }^{68}$

While much of Might's contribution to the McSweeney's business plan was the lessons learned from its failure, it did, however, contribute something that would transfer to McSweeney's. The main contribution of Might was the idea that McSweeney's should not rely on the backing of a publisher. Instead, Eggers would become the primary

${ }^{68}$ Ibid. 
financer of the magazine just as he had previously done with his partner David Moodie at Might. As Eggers stated on the copyright page of issue one, "The total bill was offset in part by a meaningful donation by one of the journal's contributors, but the majority of which was fronted by the makers of McSWEENEY'S." ${ }^{\circ 9}$ The decision to become the primary financer was important to Eggers and McSweeney's because, as Eggers stated in his interview with Siegal, "That way, there's no compromise."70 Had McSweeney's used a traditional publisher, the magazine might have not had the freedom to try a particular issue that involved an unique design because it was too expensive or the publisher may have attempted to limit certain content. Without a traditional publisher or having to cater to the whims of advertisers, however, McSweeney's and Eggers had complete freedom and total control of the magazine.

Without the revenue from advertisements and a publisher, McSweeney's was forced to consider alternative revenue streams in order to keep the magazine viable. Adding to the problem was that printing in Iceland with Oddi proved to be expensive, as Eggers would state:

Oddi isn't cheap. There was always this weird misconception that we printed in Iceland because it was cheaper here. At best, the prices were somewhat competitive with American printing costs; at worst, as when the euro got stronger against the dollar, their prices really became

\footnotetext{
${ }^{69}$ Ibid.

${ }^{70}$ Siegal, "Dave Eggers," 36.
} 
untenable.... When the printing requires handwork, of course, it gets super-expensive. $^{71}$

In order to generate revenue, McSweeney's decided to charge a high cover and subscription price for its magazine and depend on its readers for support. Its first issue sold for $\$ 8$ and a subscription cost $\$ 30$ for four issues. With each issue, the cost continued to increase as McSweeney's better grasped the costs of producing and distributing the magazine as well as the profits it was making.

Unlike any magazine before it, however, the costs and profits were painstakingly detailed in each of the first five issues. A section on the copyright page of the first issue reads:

TO ANSWER YOUR QUESTION: this journal, of which 2,500 copies were made, cost $\$ 4,109$ to print (approx. $\$ 1.64$ copy). Shipping to and from Iceland, where this was most assuredly printed, was about $\$ 1,400$, bringing the total bill to about $\$ 5,509 \ldots$. After giving away a good number of copies to those we wish to impress, we expect to sell somewhere in the neighborhood of 1,500 copies through bookstores and mail-order solicitations. At $\$ 8$ a pop, we take home between $\$ 6$ (mail-order) and $\$ 4$ (bookstores) per, which means about $\$ 7,500$ in revenue giving us a tidy little profit about $\$ 1,991 .^{72}$

The placement of the above text in an area seldom used by any type of publication would suggest that it is unimportant. However, the sheer amount of text placed on the page,

\footnotetext{
${ }^{71}$ Pruzan, "Oddi Jobs," 91-92.

72 Eggers, “Copyright Page,” Autumn 1998.
} 
which usually contains little, almost ensures that the reader will notice something is different. Of course, that doesn't ensure the reader will take the time to read through it all, but the interpellation suggests that either McSweeney's readers might be curious about the behind-the-scenes aspects of the magazine or that McSweeney's believes they should be.

In subsequent issues, the magazine includes further and more specific details of the process, suggesting that McSweeney's understanding of the complexity of the business side of the magazine was growing. The narrative of the costs and revenue also continues to address the reader:

We are passing its cost onto you, in the form of the price change mentioned above. The second reason for the hike concerns helping us cover all the bells and whistles in this and future issues. Perhaps you already saw the gatefolds. Are the gatefolds not nice? The gatefolds are nice; it cannot be denied. Do you like them? Yes? Good. You paid 36 cents for them. In addition to the gatefolds we have added more pages.... That accounts for approximately 45 cents extra, apiece. ${ }^{73}$

The narrative continues from that point to discuss added color as well as shipping, distribution, and postage costs. However, an important question still remains: why are they telling the reader all of this?

McSweeney's answers this question in issue five, which was the first issue to appear as a hardcover, and it delves even further into the business aspect of running a

\footnotetext{
73 Dave Eggers, “Copyright Page,” Timothy McSweeney's Quarterly Concern, Late Summer/Early Fall 1999.
} 
magazine. In issue five, the copyright page, where Eggers normally updated readers on the business aspects of the magazine, expanded to nine pages total for Eggers' update. In addition, an entire page was devoted to an email from Arni Sigurdsson of Oddi Printing, which detailed the size of the journal, specifications of the type of ink used, the shrinkwrapped pallets in which the magazines were shipped, and the terms of the contract McSweeney's had signed with Oddi. Though all of this highly detailed information of the business aspect of printing a literary journal given in each issue may seem inconsequential to some readers, McSweeney's finally explained in issue five why it believed it was not:

WHY ARE YOU PEOPLE ALWAYS TALKING ABOUT PRINTING AND PRICES AND NUMBERS AND SCHEDULES? IT IS NOT OF INTEREST TO MANY OF US. We realize this. But we are, right now, interested in it, deeply so. We are fascinated by how easy it all is. We are amazed by how these things are made, how long they take, how much they cost, and are naturally curious to see how it all works from here - how the books... are distributed.... When everyone is talking about electronic books... and about the future of books...we think the direction we should be going in is obvious.... Given how accessible the technology is...just about anyone can (or should be able to) easily print a book in a hardcover way, and still charge what they're starting to charge for paperbacks... and thus expect nice sales.... In short, we are talking about smaller and leaner operations that use the available resources and speed and flexibility of the 
market (i.e., the web and other consumer-driven methods), to enable us to make...better books... in a fiscally sound way. ${ }^{74}$

As I mentioned at the beginning of the chapter, McSweeney's believes that printing and publishing should not be hindered or limited by new technology, but that technology can enable just about anyone to publish quality print objects if they desire to do so. In this quotation, Eggers explains his reasoning for using both print and digital platforms rather than one or the other.

Returning to Eggers, it once again becomes apparent that he is the driving force behind these business practices. In an interview with Salon in 2005, he expanded on the conversation that issues 1-5 of McSweeney's had begun:

In terms of numbers, I think if the truth is out there for everybody, then everybody is a lot better off.... It's true, we know all the numbers. There are only four people at McSweeney's, so we all know how much a book makes, how much it costs... We know how much of the cover price the bookstore takes, how much the distributor takes, how much it costs to ship a box of books.... But it's empowering, incredibly empowering, to know how it all works. ${ }^{75}$

Eggers' comments make it clear that the conversation on the copyright pages of McSweeney's is not simply an eccentricity or elaborate joke. Rather, it is an important aspect of publishing a magazine.

\footnotetext{
74 Eggers, “Copyright Page," Summer 2000.

75 David Amsden, “The believer,” Salon, March 9, 2005, http://www.salon.com/2005/03/09/eggers_37/.
} 
A final aspect of the McSweeney's business plan is its relationship to the internet. Eggers and by extension McSweeney's frequently get mischaracterized as being hostile toward the internet and digital media, as both Eggers and McSweeney's are in Stephen Blackwell's article "Dave Eggers is a Luddite."76 Though McSweeney's clearly does not support digital publication replacing print publication—issue five refers to electronic books as "icky, cold, robotic" 77 it clearly valued new technologies as a way to provide flexibility in publishing less expensive print objects, as well as placing value in digital publication as a means to draw readers to its print magazine. Eggers and McSweeney's also believe that, while a rise in digital media does not necessarily mean the end of print media, in order to survive print media must focus on what it can do differently from digital media. Speaking on that very subject in the San Francisco Chronicle, Eggers noted, "Physical forms of the written word need to offer a clear and different experience. ${ }^{78}$

Thus, McSweeney's was among the first magazines to publish content on an internet site in conjunction with a print magazine. Timothy McSweeney's Internet Tendency began as a space to publish shorter humor pieces, with longer fiction and nonfiction saved for the print magazine. As is to be expected from McSweeney's, it planned strategically to use the internet site to support the print magazine, as current managing

\footnotetext{
${ }^{76}$ Stephen Blackwell, "Dave Eggers is a Luddite," Death and Taxes, February 7, 2011, http://www.deathandtaxesmag.com/51000/dave-eggers-is-a-luddite/.

${ }^{77}$ Eggers, “Copyright Page,” Summer 2000.

78 Julian Guthrie, "Panorama seeks to expand reach of newspapers," San Francisco Chronicle, November 24, 2009, http://www.sfgate.com/news/article/Panorama-seeks-to-expand-reach-of-newspapers3280601.php.
} 
editor Jordan Bass noted in an interview with Publisher's Weekly: “Our sense is that there's some sort of partially overlapping Venn diagram there, between readers of our Web site and readers of our books; we're always looking for ways to push those circles closer together, and keep them growing.... I think keeping that ambit wide encourages people to keep coming back, to see what's going to happen next."79 McSweeney's did not simply end their online presence at the website. In 2011, it released an app that became important for McSweeney's “as a place to try new things out and to tie all of McSweeney's projects together in one place. ${ }^{\prime 80}$ A crucial aspect of McSweeney's business plan from the beginning to the present day, then, has been not to position itself directly against new media, but to use new media as a means to generate new consumers of print media.

McSweeney's decision to incorporate new media has proven to be one of the most influential aspects of its business model. The decision not only allowed McSweeney's to remain primarily a print journal and draw in new consumers, but it also proved to other editors and writers who were considering beginning a magazine that print could remain a primary focus, especially if these new magazines incorporated new media into their own models. As I will show, new magazines like The Believer and $n+1$-not to mention The Point, Jacobin, etc. - would all follow this innovative decision first made popular by McSweeney's.

\footnotetext{
79 Gabe Habash, "Literary Magazines Adapt to the Digital Age," Publishers Weekly, March 10, 2013, http://www.publishersweekly.com/pw/by-topic/digital/content-and-e-books/article/56283-literarymagazines-adapt-to-the-digital-age.html."

${ }^{80}$ Ibid.
} 
iv. Eggers as editor

As has become clear, any discussion of McSweeney's usually begins with editor and designer Dave Eggers. Eggers has proven to be the driving force behind both McSweeney's aesthetic and its business model. Though his life story, work as a writer, and work as a philanthropist have been detailed at great length, as in Hamilton's One Man Zeitgeist: Dave Eggers, Publishing and Publicity and in various articles, his work as an editor has been frequently overlooked. In this section, I will use an important essay on the role of the periodical editor by Matthew Philpotts to contend that Eggers is arguably the most important and influential editor of his generation. Philpotts' essay asserts that there are three types of editorship: the "charismatic editorship," the "bureaucratic editorship," and the "mediating editorship," which Philpotts sees as the ideal, and uses the careers of specific editors to support his claims. While both the charismatic editorship and the bureaucratic editorship have strengths - the charismatic editorship in creating a strong aesthetic and the bureaucratic editorship in establishing a stable journal — both styles of editorship possess significant flaws as well, namely the omission of other styles' strength. Philpotts thus sees the mediating editorship as a combination of the strengths of both the charismatic and bureaucratic editorships, while also avoiding the weaknesses of each. As I will argue, Eggers perfectly fits the role of the "mediating editorship," something no other editor of his generation is able to claim.

Eggers' primary editorial influence on this generation of little magazines is to provide instruction on how a magazine can — and by implication should — be managed in order to be successful. Although Eggers' unique blend of editorial talent qualifies him as an "ideal editor" under the specifications laid out by Philpotts, his example of having a 
clear aesthetic vision, being able to both develop new writers and feature those who are already established as well as having a strong grasp of the business aspect has given this latest generation of little magazines something to model themselves after. Even though many of this generation's little magazines have editors that most closely resemble what Philpotts has described as the bureaucratic editorship, Eggers' influence, as previously shown, has affected them all.

The concept of the editor and the role that he or she plays in shaping a publication is a gap in previous literary criticism that periodical studies has begun to fill. In Women Editing Modernism: "Little” Magazines and Literary History, Jayne E. Marek examined the work of seven women editors who made significant contributions to modernist literature. Brad Evans has also touched on the role of the editor in articles like "Introduction to Le Petit Journal des Refusees," where he discusses the work of Gelett Burgess in relation to both Le Petit Journal des Refusees and his editorship of The Lark. In addition, Scholes and Wulfman have attempted to provide a way to study how particular editors influenced particular magazines in Modernism in the Magazines. In Modernism in the Magazines, they note, "editorship, especially for smaller periodicals, is a crucial unifying element, which must be considered, ${ }^{, 81}$ but do not venture much further into the concept of the editor. While this obviously is helpful in considering Eggers' role at McSweeney's it does not help in determining what type of editor Eggers is or how his editorial practices may have shaped future editors of little magazines. Recently, however, Philpotts' essay, "The Role of the Periodical Editor:

\footnotetext{
${ }^{81}$ Scholes and Wulfman, Modernism in the Magazines, 53.
} 
Literary Journals and Editorial Habitus," has provided not only a much needed explanation of the importance of an editor to a magazine, but also a way to categorize the different styles of editors that might shape a magazine.

Philpotts begins his discussion by observing that "periodical editorship depends on a dual and contradictory habitus. ${ }^{" 82}$ Essentially, this means that an editor must "mediate between the aesthetic and commercial fields" ${ }^{83}$ that a publication is involved in; he or she must be able to navigate both the aesthetic requirements of a magazine as well as the business requirements. After giving this general principle, Philpotts categorizes the editorial role into three distinct types: the charismatic editorship, the bureaucratic editorship, and the mediating editorship, while assigning a specific example to each.

Ford Madox Ford's work for The English Review is Philpotts' primary example of a charismatic editorship, described as "the subordination of the common institutional habitus of the journal to the personal habitus of the editor." ${ }^{\wedge 4}$ In other words, Ford's aesthetic sense became The English Review's aesthetic sense; he did not seek to create an aesthetic that could be maintained without him. In addition, the "relationship between the personal and institutional habitus generates a profound personal identification on the part of the editor with the journal and its core ethos.. ${ }^{85}$ In a sense, the charismatic editorship depends on an editor with both a clear aesthetic vision and the ability to

\footnotetext{
${ }^{82}$ Philpotts, "The Role of the Periodical Editor," 42.

${ }^{83}$ Ibid., 42.

${ }^{84}$ Ibid., 48.

${ }^{85}$ Ibid., 49.
} 
acquire social and symbolic capital for the journal by publishing not only well known authors that fit that magazine's aesthetic but by developing unknown authors as well. Unfortunately, the charismatic editorship, though often brilliant during its run, is also "necessarily predisposed to be short-lived, its personalized intensity and dynamism likely either to burn out in the collapse of the journal project or else undergo routinization into a more bureaucratic form." ${ }^{\prime 8}$ In Ford's case, his editorship of The English Review, though critically lauded, was brief because he was "positively inept when it came to the financial side of [the journal]. ${ }^{, 87}$

Certainly, aspects of Eggers' editorship of McSweeney's appear to be in the vein of the charismatic editorship. Like Ford, Eggers has transferred his aesthetic to the magazine and published both the most celebrated authors of his time, including Zadie Smith, David Foster Wallace, and William T. Vollmann, as well as developed relative unknowns in Deb Olin Unferth, Rick Moody, and Neal Pollack. However, unlike Ford, Eggers has been just as adept at handling the financial aspects of the magazine, which has led to a prolonged run of McSweeney's. Although Eggers exhibits characteristics of the charismatic editor, he cannot be classified as one due to the sustained success of McSweeney's.

Philpotts defines the bureaucratic editorship as a second form of periodical editorship, which is typically associated with long-standing review journals rather than little magazines. In contrast with the charismatic editorship, the bureaucratic editorship, which Philpotts associates with La Nouvelle Revue Francaise, should "not only spread

\footnotetext{
${ }^{86}$ Ibid.

${ }^{87}$ Ibid., 50.
} 
responsibility and risk across the editorial team," but also make "available a wider range of editorial dispositions than those at the disposal of...prototypically charismatic editors." ${ }^{\prime 88}$ In this form of editorship, the primary aesthetic is the journal's and the editor must submit to it, rather than the other way around. For this reason, "it is also more likely to ensure continuity and reproduction of the editorial role between successive postholders" as well as establish a "frequent reliance on a well-developed managerial infrastructure, ${ }^{89}$ allowing the journal to avoid the financial pitfalls that can lead to the demise of those with a charismatic editor. With that said, a "bureaucratic form of editorship carries its own dangers, not least the journal will lose it distinctive cultural mission and the risk-taking edge which attracts symbolic capital in the literary field." ${ }^{.90}$ With all the forms of new media in today's society, print magazines must be especially wary of these dangers that come with a bureaucratic editorship. If the magazine loses the cultural mission that initially attracted readers, then the readers can easily move on to some other magazine or form of media.

As with the charismatic editorship, Eggers' editorship at McSweeney's shares traits with the bureaucratic editorship. Over time, Eggers has employed different managing editors for McSweeney's as well as certain guest editors for particular issues. These decisions have allowed Eggers to spread responsibility across an editorial team as well as to allow him to manage day-to-day operations of the magazine and ensure that the

\footnotetext{
${ }^{88}$ Ibid., 51.

${ }^{89}$ Ibid., 53.

${ }^{90}$ Ibid., 54.
} 
business side of the magazine is in order. Yet Eggers' editorship of McSweeney's is not an entirely bureaucratic editorship, either, due to its ability to maintain its risk-taking edge and cultural mission.

Predictably then, the final type of editorship, which Philpotts calls the mediating editorship, is a balance between the two poles presented by the charismatic editorship and the bureaucratic editorship. Philpotts associates the mediating editorship with the work of T.S. Eliot in his magazine The Criterion. While Eliot's abilities as a poet and critic have been widely praised, "what is often obscured by Eliot's subsequent public image is the...importance precisely of professional and economic dispositions in his success." ${ }^{.11}$ Philpotts goes on to give a detailed account of Eliot's ability to introduce new writers while at the same time mixing in established ones, to blend different ideological and intellectual positions, and to mediate between the economic and intellectual concerns of a magazine. The ideal editor, as exemplified by Eliot, "is not only a poet and a professional, but also a politician and a profiteer, a prophet and a publicist; less a double personage than a multiple personage., ${ }^{, 2}$

Like Eliot, Eggers has achieved this ideal while at McSweeney's. Though Eggers has not sought to blend different ideological positions due to the absence of criticism from McSweeney's, he has shown an ability to blend different styles of fiction and nonfiction while also mediating between the aesthetic and business concerns of his magazine. The description of the ideal editor seems to fit exactly what Eggers' career has displayed. He is an author and a businessman, but also an advocate for the freedom of the author

\footnotetext{
${ }^{91}$ Ibid., 55.

92 Ibid., 61.
} 
and, as will become apparent in the subsequent chapter of this thesis, a publisher and champion of other little magazines. Eggers' importance as an editor, though largely ignored, has been a crucial factor in the resurgence of the little magazine. His importance as an editor, however, does not stem from other little magazine editors attempting to emulate his editorial model. As Philpotts has shown, few editors in the history of little magazines fit the role of the "ideal editor" and that trend continues to the present day. Rather, Eggers' importance as an editor comes from the creation of McSweeney's and the business model, as well as developing a literary movement around it, which revitalized little magazines in the United States. 


\section{TWO PATHS EMERGE FROM THE MCSWEENEY'S MODEL}

Although McSweeney's is the most important component of The McSweeney's

Group, McSweeney's and the actants that have shaped it are only one part of The McSweeney's Group. In the same way that McSweeney's has been influenced by and composed of these outside actants, it itself has become an actant in the development of a number of other magazines, which also are components of The McSweeney's Group. Although many of the contemporary little magazines can be traced back to the influence of McSweeny's, the magazines The Believer and $n+1$ represent a distinct and important break in the lineage of McSweeney's. On one side, The Believer has followed the McSweeney's blueprint as closely as possible, while on the other side $n+1$ has positioned itself against the aesthetic that McSweeney's espouses. Thus these two magazines exemplify the range of responses to McSweeney's influence upon the current generation of literary magazines.

\section{i. Amidst The Believers}

On the surface, McSweeney's and The Believer are tied together both by the McSweeney's publishing firm, which publishes both magazines, as well as by a group of like-minded artists and editors that work on both magazines. While they are related in these ways, the magazines also differ in the respective types of writing each publishes. McSweeney's publishes short fiction and some essays and The Believer publishes interviews, critical reviews, and poetry.

As I have argued in the prior chapter, an important aspect of the McSweeney's literary aesthetic is that it places value on human connection. However, establishing a 
connection and dialogue with its readers is a challenge for McSweeney's because it primarily focuses on fiction. While fiction can obviously lead to discussion, fiction cannot create a more straightforward dialogue, as a review or an interview might. Fiction is inherently subjective, which allows a number of readings for any particular story. Due to this, it is not the ideal form to maintain an ongoing discussion with its readership.

Although McSweeney's is limited in its capacity to establish a dialogue with its audience, McSweeney's still served a vital purpose with regards to the second generation of little magazines. Apart from creating a clear and easily adaptable business model for future little magazines like The Believer, McSweeney's also created and gathered an audience that was interested in and hungry for experimental literary content and culture. By establishing easily recognizable and respected design and literary aesthetics and filling the magazine with both well-known and up-and-coming writers, McSweeney's created "the first bona fide literary movement in decades." $" 93$

For this movement to be maintained, however, a separate magazine would be needed to keep the discussion, which McSweeney's had begun, ongoing. It is my contention that The Believer not only is this magazine, but that it has done so by using the McSweeney's aesthetic, although The Believer has transferred the aesthetic to different genres. In addition, the McSweeney's aesthetic has allowed The Believer to discuss aspects of non-literary culture with a literary sensibility, thereby not only maintaining the discussion but also extending it to include an audience that would not be immediately drawn to a literary review.

\footnotetext{
93 Franklin, "98-Pound Gorilla.”
} 
In order to support my contention with regards to The Believer's role in The McSweeney's Group, it is necessary to follow the paths of the smaller actants that compose The Believer. As became clear with McSweeney's, The Believer is both an actant in the larger network of The McSweeney's Group and composed of smaller actants itself. Once again, it seems appropriate to begin tracing The Believer section of the network with Dave Eggers, particularly because it is the McSweeney's publishing firm that publishes The Believer.

Eggers had a hand in initiating The Believer before any discussions of the magazine had even begun. As previously discussed, Eggers left interviews and, for the most part, critical essays out of McSweeney's, leaving a space for another magazine to begin by not only basing the magazine on these two genres, but also to approach these genres in a different way from most contemporary literary magazines, i.e., by looking at them through the McSweeney's aesthetic. At the time, there was no indication that Eggers did so with the idea that a separate review-based magazine was planned in the future. Had Eggers included critical reviews of novels, art, movies, etc., in $M c S w e e n e y$ 's, there would have been no need for the McSweeney's Publishing Company to publish a separate magazine, as those areas of focus would have been covered in McSweeney's.

Just as importantly, because of Eggers' distaste for the typical critical review published in other magazines, Eggers would only support and publish another magazine that fell in line with his own aesthetic beliefs about the critical review. In other words, there was not a void for a literary review magazine at the time, but a void for a specific literary review magazine that fit into Eggers' own conception of what a literary review should be. In an interview with David Amsden, Eggers discusses the initial ideas behind 
The Believer: "This magazine was designed to talk calmly, enthusiastically and intelligently about books.... with respect and civility and depth. ${ }^{, 94}$ For the creation of The Believer to occur, however, there also had to be a group of like-minded editors and writers to whom Eggers could entrust the project since his primary focus would remain elsewhere.

Many of these writers had started to come up through MFA programs. In literary scholar Amy Hungerford's article, "McSweeney's and the School of Life," Hungerford speaks with the writer Deb Olin Unferth who states that "[my creative writing classmates] all wanted to publish with McSweeney's." ${ }^{95}$ Hungerford goes on to suggest that "Unferth identifies herself as having been something of a McSweeney's writer since before she published her first stories in the quarterly." ${ }^{, 96}$ From the statements of Unferth it becomes apparent that McSweeney's was not forcing its style on writers. Rather, writers in MFA programs around the country were emulating the McSweeney's style both because the style appealed to them and also because they hoped to be published in McSweeney's. Therefore, by creating McSweeney's and the McSweeney's aesthetic, there was a group of like-minded writers and editors to staff The Believer, in part, because they had come up with McSweeney's.

Before moving on from Eggers, however, I would like to note a final aspect of Eggers' influence on The Believer. Although his name does not appear on the masthead of The Believer, Eggers created the design template that The Believer would use for its

\footnotetext{
${ }^{94}$ Amsden, "The believer."

${ }^{95}$ Hungerford, "School of Life," 663.

${ }^{96}$ Ibid.
} 
covers, as he notes in Lance Knobel's article: "We knew the design staff had to be minimal, or basically nonexistent. So the general task was to design a template that was clear and memorable, and simple and unchanging enough that one person could maintain it. ${ }^{, 97}$ The difference in design priority would be a major distinction between McSweeney's and The Believer. Unlike his work with McSweeney's where Eggers would spend a significant amount of time in designing each issue, he wouldn't be regularly working on The Believer. McSweeney's design had already done the work of drawing the audience into the McSweeney's world. There would be no need for The Believer to redesign itself with each issue. Due to the prior work of the McSweeney's design aesthetic, and to keep costs down, Eggers created a design that still has many of the hallmarks of the McSweeney's aesthetic: lots of text, few graphics and heavy paper. The innovation for the design of The Believer is its relatively easy maintenance (see Figure 2). The design gets reused every issue and the only changes to it come with new faces and different text added. Whereas the focus of McSweeney's has been both on the print object and the content, The Believer would primarily be about the content.

97 Knobel, "Little Journal,” 32. 


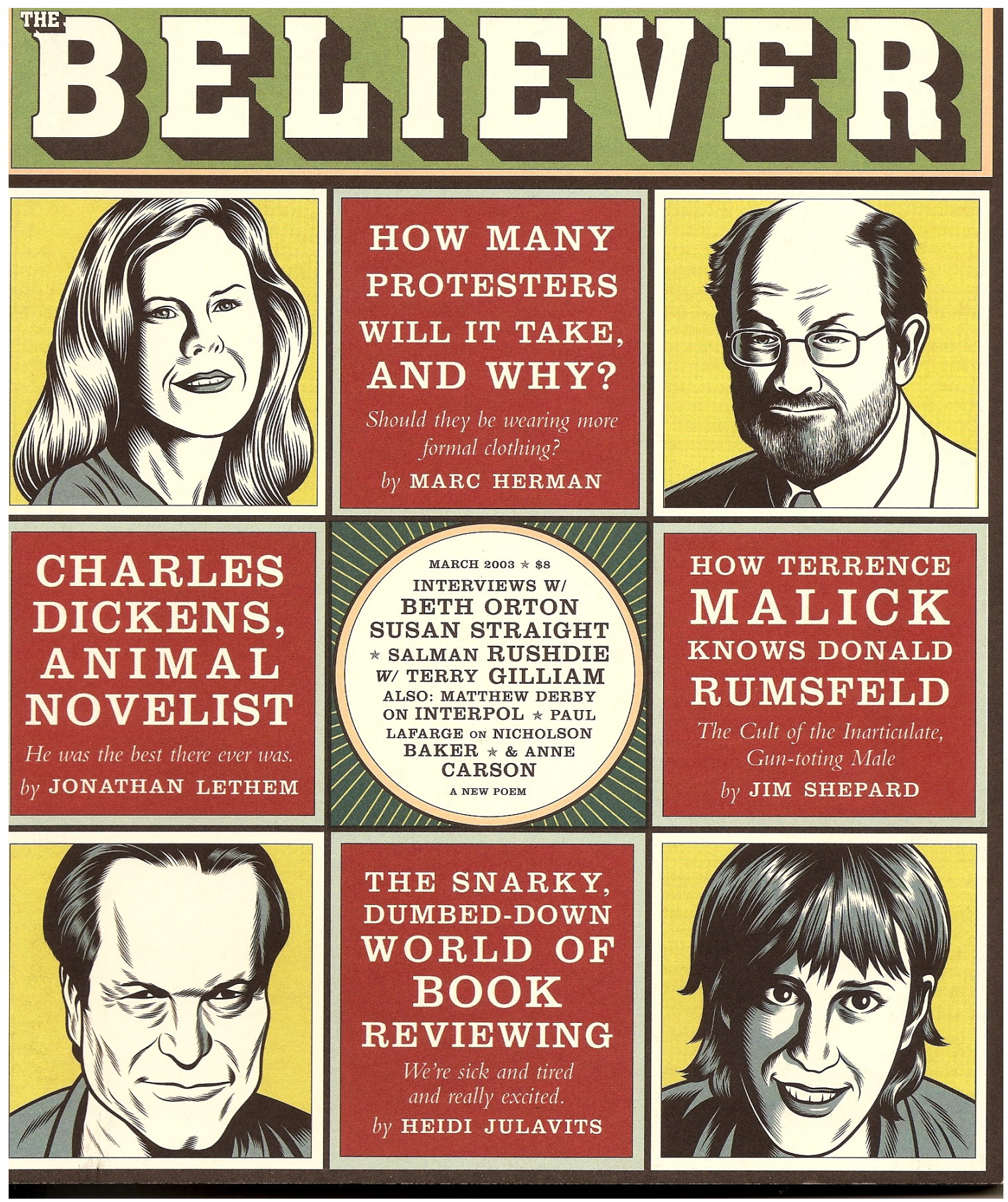

Figure 2: Cover of The Believer Issue One, March 2003. 
From Eggers, we can continue to trace the development of The Believer to its two major editors: Vendela Vida and Heidi Julavits, who are both novelists and have been the only editors to remain with the magazine during its entire run. Julavits and Vida also edit the magazine's two major sections: Julavits edits the articles and Vida edits the interviews. The link between the three editors is that Eggers and Vida are married and Julavits and Vida have been friends since their days at Columbia University's MFA program. ${ }^{98}$ Although Eggers indirectly influenced the creation of The Believer by creating a space for it in the magazine world, he also had a direct impact in The Believer's creation as well, even if it was a minimal one. In addition to designing the template for the magazine, Eggers initially discussed the idea for The Believer with Vida. As A.O. Scott notes, "The Believer grew out of the blending of two different ideas - an interview magazine Vida and Eggers were discussing and a book review Julavits was interested in starting." 99 From that point, though, the direction of the magazine has been guided by Julavits and Vida with help from a rotating cast of other editors, including at one time Eli Horowitz, who served as the managing editor for The Believer before moving on to the same position with McSweeney's.

From the beginning, Julavits and Vida intended The Believer to be primarily a book review with a small sampling of interviews, but along the way it evolved into something different. As Julavits told The Los Angeles Times, "I think it started out as a pure book review, and at its heart, that's what it is.... But in our sort of interdisciplinary

\footnotetext{
98 Renee Tawa, "New magazine has an abiding faith in the good book review," Los Angeles Times, March 31, 2003, http://articles.latimes.com/2003/mar/31/entertainment/et-renee31.

99 A.O. Scott, "Among the Believers," The New York Times, September 11, 2005, http://www.nytimes.com/2005/09/11/magazine/11BELIEVERS.html?pagewanted=all.
} 
world, books naturally spill out into these other artistic and cultural arenas. I've been calling it a book and culture review, a literary culture review." ${ }^{100}$ Unlike a standard book review, The Believer took the critical style normally reserved for reviewing books and transferred it to other aspects of culture, including other art forms like movies and music. In addition, The Believer has included articles about books that would not be considered literary in the academic sense, as in the May 2003 issue, which looked at Ashida Kim, leader in the Black Dragon Fighting Society and founder of Dojo Press. While this would not be a standard subject for the average book review magazine, The Believer's extension of the critical review to subjects like ninjas allows it to both reach and include a wider audience, as well as create a new topic for discussion among its established audience.

The editors also shared a belief in not only the value of a culture review, but also in the value of doing a certain style of review, something they believed to be absent from the majority of contemporary reviews. The style of review espoused by the editors sought to maintain "fairness and rigor when assessing the success or failure of an author's project," ${ }^{101}$ without disparaging the author or the artist. In the first issue of The Believer (March 2003), Julavits explained the need for this style of review, penning what would become the magazine's manifesto and laying out the philosophy behind the magazine in an essay entitled, "Rejoice! Believe! Be Strong and Read Hard!"

The essay shares a similar sentiment to the one expressed in Eggers' addendum from his interview with the Harvard Advocate. At times, both writers seem angry about a

\footnotetext{
100 Tawa, "New magazine has an abiding faith."

101 Heidi Julavits, “Rejoice! Believe! Be Strong and Read Hard!,” The Believer, March 2003, 15.
} 
type of response to creative work known as "snark," defined by Julavits as a "hostile, knowing, bitter tone of contempt." ${ }^{102}$ While Eggers decried snark as the tone taken by all those who claim an artist "sells out" upon becoming successful, Julavits asserted that a similar sentiment of anger and negativity was often directed at the authors of new books under review. Whereas Eggers simply dismisses snark as a response of the embittered critic, which should be ignored, Julavits sees it as something to be combated because of its harmful affects on the literary world. Due to these beliefs, Julavits actively positions The Believer against this type of reviewing:

The snark is unnecessary... [and is] frequently employed to mask an actual lack of information about books.... I believe literature has an intrinsic worth, and that I believe in fairness and rigor when assessing the success or failure of an author's project.... I also believe (perhaps naively) that there is a way to insist on rigorous standards from reviewer-writers fearing they'll never get a Guggenheim, or an NEA, or a fellowship...or another decent blurb for the rest of their lives.... Perhaps in the service of our “profession," we all need to grow up a little bit, writers and reviewers alike. Reviews should be an occasion, not for tears or vendettas or shoe licking, but for dialogues. I want to give elastic brows a forum to introduce ideas in a civil yet serious manner, and remind people of writers who were overlooked last month or thirty years ago. ${ }^{103}$

\footnotetext{
102 Ibid., 13.

${ }^{103}$ Ibid., 15.
} 
Julavits, particularly in her final comments, gives voice to the theory and goal of The Believer. It is a cultural review of both high-and lowbrow topics that discusses these topics in a civil and serious manner. The intended goal of this type of discussion is to refrain from succumbing to an either/or type of critical review. The Believer actively sought to avoid writing "snarky" reviews, those that openly displayed contempt for the author, and reviews of the opposite end of the spectrum, which praised the author or artist without any real critical assessment. By styling its reviews in this fashion, The Believer hoped to recreate a sense of dialogue that it felt had been lost by the either/or type of review.

The aesthetic influence of Julavits and Vida on the magazine hinges on the idea that Julavits put forth in "Rejoice!" of having an interest in "elastic brow" topics, topics that might be highbrow, lowbrow, or a mixture of both, and assessing these topics with rigor and respect. Since they edit different sections of the magazine, it will be helpful to look at a sampling of these articles to determine if their aesthetic sense is different or the same, and how it might have been influenced by the aesthetics of McSweeney's.

Following Julavits' manifesto, the first issue of The Believer opens with an article on Nicholson Baker, an author who probably would not be well-known to The Believer's target audience of those in their 20 s or early 30 s. Baker is a writer of fiction and nonfiction as well as a professor of Poetry at European Graduate School. The Believer's article on Baker is mostly concerned with what was then his latest novel, $A$ Box of 
Matches, but also considers his "style of close observation," 104 his relation to European and American writers, and his career as a whole.

In her interview with The Los Angeles Times, Julavits confirmed that The Believer was "aimed at cultivating a community of readers, particularly in their 20 s, who flip past traditional book reviews, ${ }^{, 105}$ so The Believer's decision to begin its first issue with Baker makes sense, based on The Believer's stated goals that the magazine would seek to create a dialogue between its younger audience and the work of an older, lesser-known writer. In addition, the style of the review is engaging because of the author's inclusion of personal anecdotes about his reading of Baker as well as the non-linearity of the review. It simply does not begin with the beginning of $A$ Box of Matches and proceed to its end. Rather, the review discusses Baker's novel in relation to both the topics I mentioned as well as a series seemingly unrelated topics listed under the article title as to be "Discussed," including, "Small Mucoid Ejecta ... Grocery Lists ... Boston ... [and] Trains." ${ }^{\prime 106}$ By giving readers a list of seemingly unrelated topics, The Believer intrigues them by inviting them to discover how these topics fit together, thereby both preventing them from skipping over the book review and introducing them to an author that the readers probably had not been aware of.

The contents of the first issue continue to follow a pattern of eclectic but engaging topics, with each article beginning with a series of seemingly unrelated topics to be discussed. Again, The Believer's strategy draws the reader in to read about a diverse

\footnotetext{
${ }^{104}$ Paul La Farge, “The Little Nicholson Baker in My Mind," The Believer, March 2003, 22.

105 Tawa, "New magazine has an abiding faith."

${ }^{106}$ La Farge, "Nicholson Baker,” 17.
} 
group of topics, both literary and not. After the Baker review, there is an article on a protest of the Iraq war that took place in San Francisco, showing that The Believer in its first issue is already more concerned with politics than McSweeney's. The next series of articles are, in order, a short article on an everyday motel in Vermont, a review of Terrence Malick's film Badlands (1973), a short article on another seemingly eccentric and random topic, the star-nosed mole, and another review on the life and work of author Charles Portis. Although Portis is probably the best-known and most highly-respected living author of Western fiction, he still is likely unknown to The Believer's targeted audience. As the introduction to the review of Portis states, "He's written four other novels, three of them masterpieces, though which three is up for debate. Here's 7,000 words about a guy you've never heard of. But should, we say."107 With this introduction, The Believer displays a clear understanding of its audience's literary sensibilities, as well as an ability to keep its audience from skipping past a review of an author that to the audience might be inconsequential. In addition to its list of unrelated topics, The Believer is able to prevent the reader from skipping past the article by using a clever title, "Like Cormac McCarthy, But Funny." 108 The Believer is aware that its readers are more likely to be familiar with Cormac McCarthy than they are with Portis and use McCarthy's name and stature as a way to draw the reader in by suggesting that Portis is a more humorous version of McCarthy.

Although the magazine has abandoned its original pattern in some of its more recent issues, all of the first year's issues roughly follow the same pattern put forth in the

${ }^{107}$ Ed Park, "Like Cormac McCarthy, But Funny," The Believer, March 2003, 49.

108 Ibid. 
first issue, with some recurring themes in the shorter articles like "mammal," "tool," "child," and "idea share," which is a way for the magazine to achieve certain goals. The recurring themes allow The Believer to create and facilitate discussion among an informed audience interested in and invested in literary culture. By using recurring topics, The Believer creates a sense of familiarity and comfort for its readers, which allows The Believer to then include topics that the reader might not be so comfortable with. The editor's approach to the magazine's contents fits with Julavits' manifesto, which announced The Believer's intention to give elastic brows—ostensibly meaning both high-and lowbrow topics - a place for serious discussion and with reminded the audience of authors who have been overlooked.

Clearly, Julavits' aesthetic shares much in common with the literary aesthetic of McSweeney's. In both magazines, there is eclectic subject matter, which is at times either written about humorously or discussed in a humorous way. Both magazines also approach the subject of books and reading from different and humorous ways as well. For example, the second issue of The Believer (May 2003) contains an article by Michael Atkinson that discusses how his life has been enhanced by large collections of unread books, many of which he stole in his younger years, something that may just as well have fit into McSweeney's. Atkinson approaches the subject of unread books - for many a source of shame - in a humorous fashion. He writes, "Who doesn't love their unread books more intensely than their read? ... the happiness that comes from not merely reading books, but possessing them," ${ }^{\prime 109}$ and finds that his life is enhanced by living

109 Michael Atkinson, "O Biblioklepts!” The Believer, May 2003, 56. 
among books. Atkinson's discussion of his own days as a thief leads him to a more extensive look at book thievery, specifically, "the first book thief .... The Turkish king Eumenes. $" 110$

In a similar fashion, an article by Ben Marcus in issue five of McSweeney's (Summer 2000) examines how the type of foods we consume can enhance our reading. In "Literary Enhancement Through Food Intake: A Dietary Guideline for Reading," Marcus posits, "I believe there is a clear-cut way to optimize the reading experience through an eating program that best disposes the reader's body toward a story." Although the article is mostly satirical, the suggestion gets made that books and reading are important enough for readers to change their dietary habits in order to better optimize their reading experiences. Atkinson and Marcus' articles take a humorous approach to talking about books in a different way, while still examining the value that books have in our lives.

In addition, as with McSweeney's, The Believer clearly values human connection, both in Julavits' initial manifesto and in many of the articles that follow. The Believer seeks not only to introduce the reader to something they have never heard about, but also to create a dialogue with them about that subject, which, as I outlined above, is where The Believer supplements the limitations of McSweeney's. In an attempt to take that dialogue and connection even further, one of the recurring articles is called "Idea Share," which "regularly offer[s] ideas for books or stories or works in other media, from those

110 Ibid.

${ }^{111}$ Ben Marcus, "Literary Enhancement Through Food Intake: A Dietary Guideline for Reading," Timothy McSweeney's Quarterly Concern, Summer 2000, 165. 
who cannot act upon them. In all cases they are offered in the hopes that these worthy projects will find their way to someone with the time and wherewithal to pursue them."112 With the establishment of "Idea Share" as a recurring article, The Believer attempts not only to create a dialogue with its readers, but also to encourage creative contributions to the magazine from its readers. While most magazines have some sort of dialogue with their readers through a letters to the editor section (and The Believer does as well), the letters are usually brief responses to an article in the previous issue of the magazine, which hardly constitute a true dialogue. However, with "Idea Share," The Believer is truly trying to establish a connection with its readers and build a relationship by allowing them to become involved in the creation of an article in the magazine. At the end of "Idea Share" in the first issue, The Believer states, "We had to make up all these ourselves. That's not how it's really supposed to work. Email your contributions to ideas@believermag.com." ${ }^{113}$ Whether or not any tangible project is produced is not the point, but rather the purpose of this recurring article is to reach out to the reader in hopes of establishing a connection.

Finally, in some of the shorter pieces there is definitely a sense of allowing authors room for experimentation. The eclecticism in the shorter pieces appears to stem from allowing the writer the freedom to write about a star-nosed mole or a light fixture from an 1888 catalogue, as Julavits does in the second issue. In the shorter pieces, the eclecticism fails to be consistently successful. Some pieces like "Motel: Shady Lawn, White River Junction, VT" in issue one are not particularly interesting or funny. Others

112 “Idea Share," The Believer, March 2003, 16.

113 Ibid. 
like "Mammal: Star-nosed mole," might not be funny but are informative and engaging, which makes the reader want to read further about the subject. Of course, it is hard to expect that each of these wildly divergent topics would be of interest to every reader of the magazine.

Apart from my contention that both The Believer and McSweeney's have different purposes, there are further significant differences in terms of the layout, the genres present in the magazine, and the more political nature of The Believer's early issues. Yet, it is clear that many of the McSweeney's hallmarks are found in The Believer as well. While many of these hallmarks can be traced back to the relationship between Eggers, Julavits and Vida, another part can be traced to the many familiar names that appear in both magazines as well. In just the first couple of issues, names like Julavits, Lethem, William T. Vollman, Rick Moody, and Wells Tower stand out as writers who have published in both magazines and write in a style that suits both magazines' aesthetic sensibilities.

Of course, Julavits' section constitutes roughly half of the magazine. Perhaps there is a different aesthetic to be found in the interviews portion, edited by Vida? After a sampling of the interview section, however, it appears that much like the articles, the interviews share a similar aesthetic sensibility. In the first issue there are interviews with Galen Strawson, a philosopher, and Susan Straight, an author, along with Beth Orton, a singer-songwriter, and Kumar Pallana, an actor best known for his roles in three of Wes Anderson's films. Again, there is a sense of the "elastic brow," a blending of high, middle and, low culture, in the types of individuals interviewed by The Believer, which 
complements Julavits' aesthetic as displayed in both the manifesto and the articles section of the magazine.

Yet the similarities between the major sections of the magazine do not end with the topics chosen. While some of the interviews in The Believer are straightforward, meaning the interview subject is only asked about topics related to their profession, as in the interview with Strawson, other interviews are strange and humorous. In the second issue, for instance, there is an interview with the rock musician Jack White, best known for his role in the band The White Stripes. Knowing the interviewee, a reader might expect questions about upcoming albums, tours, or where White sees his music heading. In a bizarre twist, however, The Believer interviews White almost entirely about upholstery, asking such questions as "What kind of materials did you work with? Metal, wood?"114 The interview is funny in a nonsensical fashion since The Believer has the opportunity to interview a famous rock musician and chooses to ask him questions only about his upholstery hobby. However, it is also another example of the magazine seeking to introduce its readers to a topic they might not be familiar with, while also creating a discussion with them. Ostensibly, the readers of The Believer would know who Jack White is and would likely have read interviews with him that discussed his music career. Simply providing another one would have created little discussion. However, by interviewing Jack White about his upholstery hobby, The Believer was far more likely to give its readers something new to discuss.

Scanning the interviews conducted in The Believer indicates that Julavits and Vida do, in fact, share a similar aesthetic. Both seek to create a blend of high and low

114 Tobias de la Manzana “Jack White,” The Believer, May 2003, 75. 
culture, and their articles and interviews often contain eclectic subjects and discuss these subjects in an earnest and, occasionally, humorous fashion. The shared aesthetic is also heavily influenced by the aesthetic of McSweeney's, both because it is published under the McSweeney's imprint and also because of the strong relationships and shared beliefs of the three major editors of the magazines.

The influence of McSweeney's on The Believer does not simply end with their aesthetics. The initial business model of The Believer was essentially the same model used by McSweeney's. As Eggers indicated in his interview with The Progressive, The Believer had small circulation numbers of somewhere between 17,000 and 20,000, depending on the issue. Although The Believer now contains advertisements, the magazine initially featured no advertisements, just as McSweeney's initially had, and instead relied on a high cover charge of $\$ 8$ for its initial issues. While The Believer's cost is significantly less than the average of $\$ 20$ that McSweeney's eventually charged, The Believer prints ten issues annually whereas McSweeney's prints three or four. In addition, because of its constant design template, The Believer does not cost as much to produce as the ever changing and lavish McSweeney's. The Believer was initially also printed outside of the United States by a printer in Winnipeg, just as McSweeney's was initially printed in Iceland. ${ }^{115}$ Like McSweeney's, The Believer maintains a small online site as a means to entice readers to purchase the print copy, by showcasing excerpts from upcoming articles. Although none of this information is particularly surprising since The Believer is published by the McSweeney's imprint, it does show that the editors of The

\footnotetext{
115 Heidi Benson, “The War on Snark," San Francisco Chronicle, July 13, 2003, http://www.sfgate.com/magazine/article/THE-WAR-ON-SNARK-THE-BELIEVER-A-little2602985.php\#page-2.
} 
Believer saw value in the McSweeney's business model and chose to use similar methods. It is also important to note that the business model has been just as successful for The Believer as it has for McSweeney's. The Believer recently celebrated its tenth year. As an actant in the network then, The Believer is important as a part of The McSweeney's Group for two reasons. First, the magazine's success proved that the McSweeney's model was not simply a fluke and that the aesthetic that was valued by McSweeney's in terms of fiction was not only one that could be translated to other genres, but also one that consumers would desire in other genres. After the success of The Believer, the McSweeney's imprint has published two other magazines that have followed the same business model and translated the aesthetic values to further genres: Lucky Peach, a food magazine, and Grantland Quarterly, a publication focusing on sports and pop culture. Second, the success of The Believer further extended the movement begun by Eggers and McSweeney's by creating a dialogue within the literary community that McSweeney's had created.

As The Believer began its second year, a new little magazine was in its development stages. Although it too would follow the McSweeney's model in some respects, $n+1$ also sought to challenge McSweeney's and The Believer's increasing cultural authority. In an online interview with Big Think, Keith Gessen, a founding editor of $n+1$ stated:

I still think [McSweeney's is] wrong about just about everything.... For us, they've been a very useful foil.... One of the things is the, I think, the nichification of literature, right?.... Where literature becomes a pretty object that you buy, a pretty object that you have on your table.... It's not 
what I think literature ought to be.... I think literature ought to be a battle of ideas. ${ }^{116}$

With this pronouncement, $n+1$ made clear that it desired to have a say in the negotiation of what would become of the new literary movement that had begun with McSweeney's and was supplemented by The Believer. Just as Scholes and Wulfman asserted that the modernist little magazines were an arena for the terms of modernism to be negotiated, these contemporary little magazines of The McSweeney's Group were, to use Gessen's phrase, set to conduct a similar "battle of ideas."

ii. $n+1$ and the Aesthetic Disagreement with McSweeney's

If The Believer represents one path a little magazine might follow in the wake of McSweeney's, then $n+1$ represents another. While in its first issue $n+1$ clearly positioned itself against McSweeney's by criticizing McSweeney's literary aesthetic and advocating for the value of its own literary aesthetic, it is still very much a part of The $M c$ Sweeney's Group. My contention is that $n+1$ 's own aesthetic differs from that of McSweeney's and The Believer, first and foremost in the fact that it is far more focused on contemporary political issues. Although $n+1$ contains fiction and book reviews, it is far more polemical in its writing than either McSweeney's or The Believer. Although it is often polemical, $n+1$ 's aesthetic is also based in the belief in serious yet civil critical discussion of politics, literature, and culture. Before analyzing the differences in the literary aesthetics between McSweeney's and The Believer and $n+1$, I will also posit that $n+1$ 's most

\footnotetext{
${ }^{116}$ Keith Gessen, "Does n+1 have beef with Dave Eggers," Big Think, May 13, 2008 , http://bigthink.com/videos/does-n1-have-beef-with-dave-eggers.
} 
important contribution to The McSweeney's Group is its development of a different literary aesthetic while adhering to other aspects of McSweeney's model.

$n+l$ 's contribution is crucial for two major reasons. First, it has shown other little magazines that the McSweeney's model can be useful, even if the literary aesthetic is not followed, and this innovation has created a second path for contemporary little magazines to follow. In other words, without $n+1$ the McSweeney's model could only have been useful to a limited number of magazines. There are only so many magazines that can copy the model, specifically in terms of its literary aesthetic, before there are simply no more genres to transfer that aesthetic on to. Since $n+1$ challenged and positioned itself against this literary aesthetic, it proved that the McSweeney's business plan and the design aesthetic were important to adopt, while also showing that future magazines could create their own literary aesthetic. In the time since $n+1$ first gave life to this idea, a number of magazines, including The New Inquiry, Jacobin, and The Point, have, essentially, aligned themselves with $n+1$. Although these magazines don't agree with the literary aesthetic of McSweeney's and The Believer, they are undoubtedly influenced by McSweeney's and The Believer.

I also contend that $n+1$ 's restructuring of the McSweeney's model was the final step in creating The McSweeney's Group. Without $n+1$ 's challenge of McSweeney's literary aesthetic, McSweeney's influence would be limited to those magazines the McSweeney's imprint published, along with the few that may have tried to copy the McSweeney's model in its entirety. However, because $n+1$ showed it was possible to succeed by taking certain aspects of the model, while also maintaining its own literary aesthetic, the McSweeney's influence has spread much further than its own immediate 
circle of like-minded magazines. Of course, without the initial model, it could be argued that this new group of magazines following in the footsteps of $n+1$ would have never existed in the first place. However, without the innovation to the model provided by $n+1$, McSweeney's likely would not have had the incredible influence upon this new wave of contemporary magazines.

In addition, without $n+1$ 's challenge of McSweeney's and The Believer, The McSweeney's Group would be far less valuable as a forum for artistic debate. As I discussed earlier, Scholes and Wulfman contend in Modernism in the Magazines that the primary value of the modernist little magazines was that they served as a place for discussion and debate about the modes and styles that would eventually become modernism. Through The McSweeney's Group, a similar debate is occurring, only about contemporary aesthetic modes and styles. Without $n+l$ 's challenge of McSweeney's, there would be no debate.

The contemporary debate began in the Fall of 2004, with the publication of $n+l$ 's first issue, a little more than a year after The Believer's first issue was published. Just by scanning $n+1$ 's opening pages, readers could clearly see that $n+1$ saw much to criticize about the current state of literary magazines. In its opening editorial, referred to as "The Intellectual Situation," $n+1$ launched sharp criticisms against the New Republic and the Weekly Standard. Its sharpest criticisms, however, were reserved for McSweeney's and The Believer, magazines $n+1$ labeled as "A Regressive Avant-Garde." 117

117 “A Regressive Avant-Garde,” n+1, Fall 2004, 7. 
As network theory has shown us, Eggers has been the beginning point to trace influences among other magazines within The McSweeney's Group, and he is still the best starting point to trace the division that grew between $n+1$ and McSweeney's and The Believer. To start with, Eggers' design of The Believer has clearly been influential upon the design of $n+1$. Even though $n+1$ has mocked the eccentric design of McSweeney's, saying in "The Intellectual Situation" that "It's a literary magazine! No, wait, it's a grouping of fourteen multi-colored booklets printed in Iceland on sealskin," ${ }^{, 18}$ the editors of $n+1$ essentially adopted the major aspects of The Believer's design and put their own spin on it.

For example, when Eggers designed The Believer template, he sought to create something clear and memorable that would be changed in small ways with each issue, both to keep design costs down as well as to provide a recognizable cover for the magazine. Just like The Believer, $n+1$ has a simple and memorable design that exhibits only slight changes for each issue. Each issue of $n+l$ has the magazine's name in large black text along with a small rectangular box that contains the titles of the feature articles for that particular issue. Whereas the colors and faces featured on The Believer change with each issue, $n+l$ has its own template and changes the color and minimal graphics for each issue. Essentially, $n+1$ uses the exact same design aesthetic as The Believer, one that was created by Eggers (see Figure 3).

118 Ibid. 


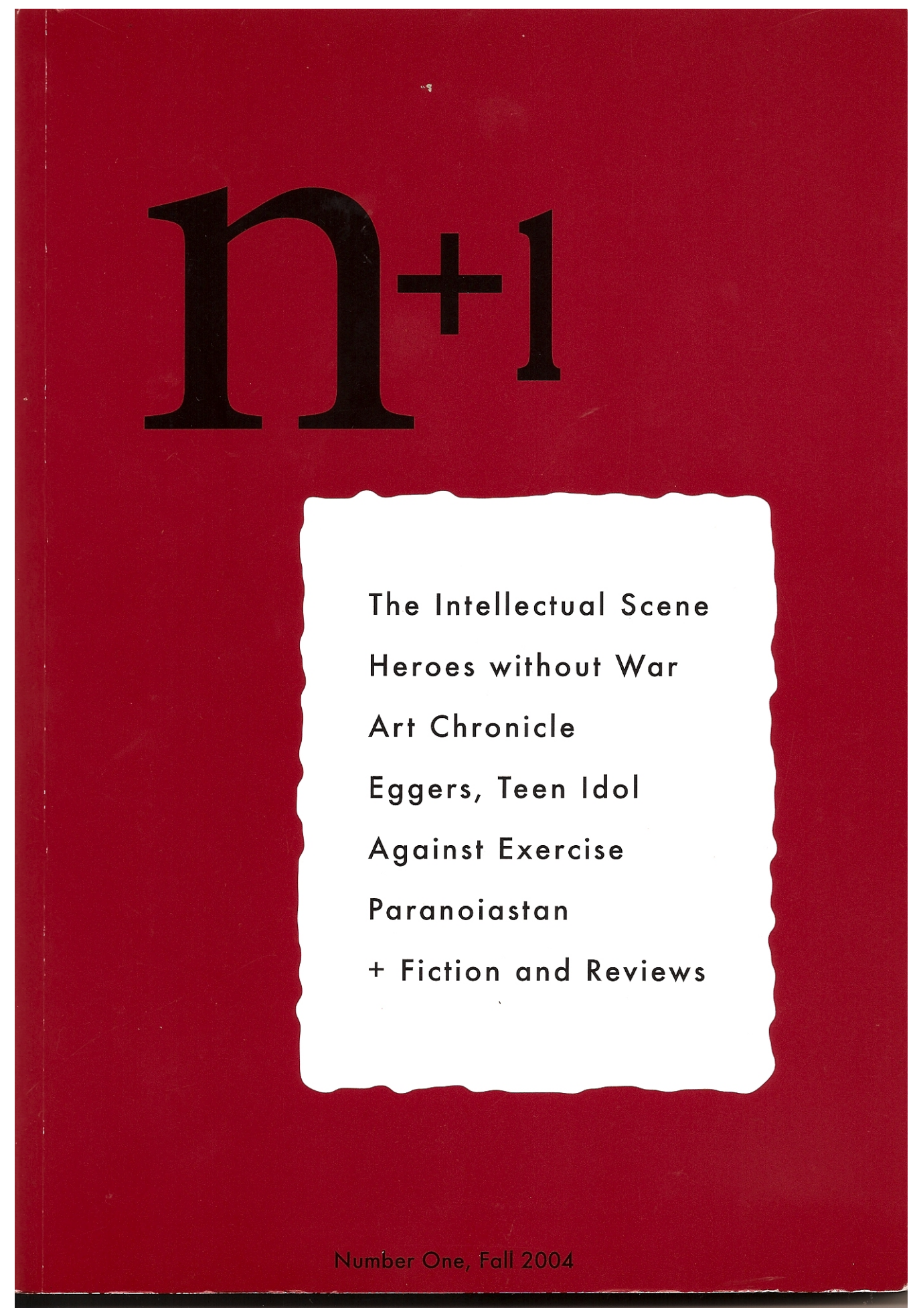

Figure 3: Cover of $n+1$ Issue One, Fall 2004 
Similarly, $n+1$ has followed the business model put forth by McSweeney's. Like McSweeney's, $n+1$ started off with very small circulation numbers. As A.O. Scott notes, the magazine "sold out its 2,000-copy first issue [and] has increased its run with every subsequent issue," just as McSweeney's had done. ${ }^{119}$ In addition, like both McSweeney's and The Believer, $n+1$ has used an online website in order to publish content that might draw the reader toward purchasing a single issue or a subscription in print. A structural similarity among all three publications' business model is that each primarily focuses on the print object, while using the internet in a secondary fashion as a way to draw new readers to the print publications. Keith Gessen, an editor of $n+1$, has commented on this approach: "We have way more readers of our Web site than we used to, as more serious readers come online, share articles, discuss them, etc.... The downside is that a lot of people think of us as primarily a Web publication, whereas, in fact, for all sorts of historical and personal reasons the print magazine remains our focus." ${ }^{, 120}$ Gessen's comments support the point that these publications share a similar business model and remain conscious of placing the emphasis on the print publication over the digital publication.

There is, however, one difference between the McSweeney's business model and $n+1$ 's. Unlike the initial issues of McSweeney's and The Believer, $n+1$ has included advertisements from the beginning of its run. With that said, though, the advertisements are minimal and often for upcoming books, for other contemporary magazines that $n+1$ supported, or for cultural events. So, although it is a difference in the model, it is not

\footnotetext{
119 Scott, "Among the Believers."

${ }^{120}$ Habash, "Literary Magazines Adapt."
} 
radically different from McSweeney's because the advertisements clearly were not paying for the costs of printing the magazine. $n+1$ still relied on subscriptions and reader funding as a way to pay for the majority of the costs of the magazine. In fact, The Believer now features ads of a similar type to those featured in $n+1$. If anything, the advertisements aided in helping keep the cover and subscription price down.

Tracing Eggers and the McSweeney's influence to $n+l$ has shown that, in many ways, $n+1$ has followed the McSweeney's model, just as The Believer had before it. This alone makes it a magazine worthy of inclusion within The McSweeney's Group. Like The Believer, it reinforced the notion that the McSweeney's model, both its business and design components, was the most successful way to run a print-based little magazine in the digital age. Yet the importance of $n+1$ to The McSweeney's Group does not stem solely from its complete adherence to the principles laid out by McSweeney's and subsequently followed by The Believer. Rather, its importance to the group is due to the fact that it attempted to step out from the McSweeney's shadow by developing an aesthetic that radically differs from McSweeney's and The Believer and thus provides an alternative path for future magazines to follow.

This aesthetic decision can be traced to the founding editors of $n+1$, all of whom met through various school ties. Although the founding editors include Gessen, Benjamin Kunkel, Mark Greif, and Marco Roth, only Gessen and Greif have spoken publicly about their opposition to McSweeney's literary aesthetic. In discussing McSweeney's, Greif noted: “our immediate antagonist at the time was McSweeney's, and then its adjunct the Believer.... They seemed to us to embody the sense of closure, of acceptance of the existing terms, 'the end of history.' It seemed that if such enterprises 
stood out as all the resistance our generation could muster, we were sunk."121 These two editors saw $n+1$ as positioned against McSweeney's, both because of what they viewed as McSweeney's objectification of literature, and because of Grief's notion that McSweeney's was too accepting of the current cultural conditions.

The answers given by Grief and Gessen (which was included at the end of the section on The Believer) are rather diplomatic, one could say. These answers do not openly mock McSweeney's, as $n+1$ 's opening section on McSweeney's would, nor do the answers point to specific flaws in the magazine's aesthetic. In $n+1$ 's first issue (Fall 2004), the four editors co-wrote a much more scathing critique of the McSweeney's literary aesthetic. Before the critique began, however, the editors conceded that “McSweeney's was briefly a significant magazine" and that Eggers' "genius for creating institutions of less elitist literary culture ... is beyond question. And if his group restarts the engine of literary innovation and strife, then it will have performed a real historic service." $" 122$ In these ways, then, $n+1$ is not completely distancing itself from McSweeney's; its editors see some value in what the magazine has accomplished as a literary movement.

However, the editors see far less value in the content of the magazine: "As far as the content goes, though, the innovation of the Eggersards was their creation of a regressive avant-garde. The first regression was ethical. Eggersards returned to the claims of childhood. Transcendence would not figure in their thought. Intellect did not

\footnotetext{
121 Mark Greif, “Little Voice,” New Statesman, April 18, 2012, http://www.newstatesman.com/culture/2012/04/american-writing-special-\%E2\%80\%94-little-voice.

122 “A Regressive Avant-Garde,” n+1, Fall 2004, 7.
} 
interest them, but kids did." ${ }^{\prime 23}$ The editors noted Eggers' memoir, which tells the story of how he raised his younger brother after both his parents died, along with his work in publishing young adult writing and establishing tutoring centers, as proof of McSweeney's preoccupation with children. After critiquing McSweeney's content, $n+1$ shifts its focus to The Believer. The editors note that The Believer "presents their version of thinking — as an antidote to mainstream criticism, which they call snarkiness.... Mere belief is hostile to the whole idea of thinking. To wear credulity as one's badge of intellect is not be a thinker as such.... It believes in others, instead of itself." ${ }^{\prime 124}$ Clearly, $n+1$ sees significant flaws in the literary aesthetic of its adversaries and wants to distance its content from the content provided by McSweeney's and The Believer.

The content was not the only thing $n+1$ attacked, however. Its editors also attacked McSweeney's design aesthetic in "The Intellectual Situation": "The second regression was technical and stylistic. In typography and tone the Eggersards adopted old innovations, consciously obsolete maneuvers from earlier moments of creative ferment.... What the Eggersards did do was reliably void these old methods of their classic interest in a search for truth.... Rejecting the new, and the true, Eggersards attacked the avant-garde hope for any transcendence of present conditions. ${ }^{\text {} 125}$ This criticism of the design alleges that McSweeney's revived old design methods, but did so after they were past any kind of value as a tool to search for truth, something that $n+1$ views as an important function of a literary magazine. At the same time, the editors of

\footnotetext{
${ }^{123}$ Ibid., 7.

${ }^{124}$ Ibid., 8.

${ }^{125}$ Ibid., 7.
} 
$n+1$ also allege that, by adopting these old forms, McSweeney's also rejected new forms, thereby displaying contentment with the present conditions of art and culture, which, again, is something $n+1$ opposes.

Even after publishing the editorial, $n+1$ was not finished with its attack on Eggers and McSweeney's. In a lengthy article in the same issue titled "Eggers, Teen Idol" and written by Gessen, $n+1$ chronicles the story of a blogger who followed Eggers' every career move. In summation, the article is a criticism of Eggers' entire career, which Gessen views as one riddled with entitlement and faux-intellectualism. The article ends by saying, "Why, in Gary's [blog], did the New York media insiders, the editors of lifestyle magazines and the authors of their puff pieces, all so insistently cry 'Phony!' whenever Dave Eggers came up? Evidently they knew he was one of them, and they were amazed he could get away so long with pretending otherwise. Of course, they were right." 126 The criticism of Eggers here is scathing and, as noted above, constitutes only a small portion of the time that $n+1$ spent critiquing Eggers and McSweeney's in its first issue.

Overall, $n+1$ spent 24 of 182 pages criticizing McSweeney's and The Believer or about 13 percent of its first issue. To devote 24 pages in their opening issue to criticism of McSweeney's, The Believer, and Eggers, might seem like an odd choice for $n+1$ to make. For $n+1$, however, it was an important one because the editors realized the enormous influence of McSweeney's over any literary magazine that would start after it, including their own. McSweeney's had only begun in the fall of 1998, just six years before $n+1$ would publish its first issue in 2004, and The Believer only a little over a year

${ }^{126}$ Keith Gessen, “Eggers, Teen Idol; or, The Education of Gary Baum,” $n+1$, Fall 2004, 61. 
before $n+1$, but $n+1$ could clearly see that both magazines had already exerted and would continue to exert a strong influence over future magazines. This realization becomes clear insofar as $n+1$ was able to dismiss both The New Republic and The Weekly Standard, two other magazines it saw as competitors, in a combined four pages. Therefore, $n+1$ primarily viewed McSweeney's and The Believer as its most significant contemporaries.

If $n+l$ 's literary aesthetic is not that of McSweeney's and The Believer, then what do its editors espouse? To begin, they focus much more of the magazine's content on political issues. Although Greif notes that " $\mathrm{n}+1$ has always been a literary magazine before anything else," he concedes that "it was two earthquakes in politics, bookending these past eight years [the U.S. invasion of Iraq in 2003 and the Occupy Wall Street movement in 2011], which most energized and defined the magazine. In that sense, it is a political journal." ${ }^{, 127}$ Perhaps the other defining characteristic of the $n+1$ literary aesthetic is the editors' desire to take serious cultural criticism back from "the exclusive province of bullies, reactionaries, and Englishmen" in order to "find the new, or take what we know from the past and say it with only the care that the living can claim." ${ }^{, 128}$ In a sense, $n+1$ has used their aesthetic concerns as a platform for promoting a serious, civil discussion in search of the truth, something they believed contemporary little magazines like The Believer and McSweeney's were not providing.

If that idea sounds familiar, it is because, in many ways, it is very similar to The Believer's own aesthetic goals. In his article on the two magazines, Scott accurately

\footnotetext{
${ }^{127}$ Greif, "Little Voice."

128 "Editorial Statement," n+1, Fall 2004, 3.
} 
noticed many similarities between the two as well. Scott criticizes $n+1$ for oversimplifying The Believer's aesthetic, noting that The Believer is about more than simple credulity. He also notes that as much as $n+1$ wants to distance itself from The Believer, the two magazines are more similar than the editors of $n+1$ might like to admit: Their ringing, programmatic insistence on progress...can sound an awful lot like The Believer's defiant optimist. And Gessen's declaration, on the last page of the first issue, that 'it's time to say what you mean,' chimes with The Believer's stance against what Julavits calls 'high irony'.... In the end, this may be the common ground $n+1$ and The Believer occupy: a demand for seriousness that cuts against the ingrained generational habits of flippancy and prankishness. Their differences are differences of emphasis and style. ${ }^{129}$

In some ways, $n+1$ also blends the genres that McSweeney's and The Believer kept separate, as it includes both fiction and criticism. $n+1$, though more topical than either The Believer or McSweeney's, is also prone to publishing eclectic subject matter. In the first issue, for example, there was an article on the merits of not exercising, something that would fit well in The Believer. There has even been a small sampling of contributors who publish work in both magazines, with a particularly noteworthy example being Kunkel who published work in the second issue and fifth issue (August 2003) of The Believer.

Although $n+1$ has positioned itself against McSweeney's and The Believer with regard to their literary aesthetic, the influence of McSweeney's upon $n+1$ is still

${ }^{129}$ Scott, "Among the Believers" 
unmistakable. $n+1$ has used both the business model laid out by McSweeney's and the design aesthetic created by Eggers for The Believer. In addition, as Scott points out, although $n+1$ positions itself against the McSweeney's literary aesthetic, it resembles The Believer more closely than it would like to admit. Finally, and this cannot be overstated, $n+1$ viewed McSweeney's as such an important and influential little magazine that it felt the need to spend such a large portion of its opening issue criticizing McSweeney's. If McSweeney's had not been influential on $n+1, n+1$ would have easily dismissed McSweeney's in a page or so, as it had done with the Weekly Standard and the New Republic.

With its critique of McSweeney's in its first issue, $n+l$ began the debate within the forum of The McSweeney's Group. Since I have limited the period of my study, I will include only one more example to show that the debate continued after the first issue. In May of 2005, $n+1$ would continue the debate with McSweeney's in Marco Roth's "Revenge of the Regressive Avant-Garde." The essay published on the $n+l$ website was primarily critical of the writer Michael Chabon, who is often associated with the McSweeney's writers (Chabon edited issue ten of McSweeney's in 2002 and has an essay collection, Maps and Legends, published by the McSweeney's publishing firm). The article examined a disagreement between Paul Maliszewski, who himself was once a writer associated with McSweeney's through his position as web editor and role as guest editor of McSweeney's eight (2002), and Chabon. The article Roth examines is from the 
New York Times, which looks at Maliszewski's accusation that Chabon was guilty of "unethical fiction writing." 130

Roth asserts that Maliszewski was correct in his assessment of Chabon but that in reports of the dispute Chabon has been presented in the more favorable light, due to the protection of Eggers. As support, Roth points to the New York Times article and claims that it "does not actually address the substance of Maliszewski's essay; instead it casts doubt on it by attacking the author's credibility in the plainest possible way." ${ }^{, 131}$ In Roth's analysis, the New York Times uses Eggers to slander Maliszewski, by having Eggers comment on Maliszewski's time at McSweeney's, which ended in disagreement between the two men and the firing of Maliszewski from his position. Therefore, the "regressive avant-garde," $n+1$ 's term for McSweeney's and The Believer, takes its revenge on those writers that seek to challenge it by attacking their credibility and not their argument, yet another problem Roth and $n+1$ see with McSweeney's.

During its run, $n+1$ has not only been critical of McSweeney's, as was displayed by its attack on the Weekly Standard and the New Republic in its first issue, but also of other little magazines and other more established literary magazines as well. In its Winter 2013 issue, for example, $n+1$ was critical of both Harper's and the Atlantic for both magazines' treatment of women. As I have argued, then, this willingness to use the contemporary little magazines as an arena to debate the artistic styles and modes of its

\footnotetext{
${ }^{130}$ Marco Roth, "Revenge of the Regressive Avant-Garde," nplusonemag.com, May 6, 2005, http://nplusonemag.com/revenge-regressive-avant-garde.

${ }^{131}$ Ibid.
} 
era— just as the modernist magazines did—along with its repurposing of the McSweeney's model, is the primary value of $n+1$ within The McSweeney's Group. 


\section{CONCLUSION}

Even though it has been possible to trace the influence of McSweeney's and The McSweeney's Group during a brief period, it is impossible to get a complete picture of the network because it is still very much active. All three major magazines, McSweeney's, The Believer, and $n+1$, continue to publish new issues according to their respective schedules. In addition, new magazines that bear the influence of The McSweeney's Group seemingly appear each year. For example, both Grantland Quarterly and Lucky Peach, new magazines published by the McSweeney's imprint were launched in 2011, and The Point released its first issue in 2009.

The work that I have set out to accomplish here cannot provide a complete mapping of The McSweeney's Group. To do so would be impossible. Rather, my goal has been to examine the influence of a particular little magazine, McSweeney's, and to reveal the ways that parts of its model have spread in the world of recent little magazines. In addition, I have analyzed how McSweeney's and the other paradigmatic examples of The McSweeney's Group have operated as actants within a larger network as well as suggested reasons for why they have been able to maintain a prolonged period of success.

One may question the treatment of McSweeney's as the genesis for this new wave of little magazines when many of these magazines (McSweeney's included) claim to be influenced by past magazines, some of which are relatively contemporary. I will conclude my thesis by addressing this potential objection and by clarifying why McSweeney's itself should be viewed as the central actant in the network that this thesis has mapped and analyzed. 
If there were a contemporary magazine that could take the place of McSweeney's at the head of the group it would be The Baffler. Both McSweeney's and $n+1$ have cited The Baffler as a major influence for their own work. In his interview with the Harvard Advocate, Eggers discussed The Baffler's long-time editor Tom Frank: “Tom Frank, for example, matters.... He has for a decade been doing work that matters." ${ }^{132}$ Eggers' comments show a familiarity and an awareness of Frank's work with The Baffler, while also likely revealing that The Baffler has influenced McSweeney's. Similarly, Grief also discussed the influence that The Baffler had on $n+1$. Grief notes, "The immediate predecessor to $\mathrm{n}+1$, and a magazine we idolized in the Nineties was Chicago's the Baffler.... It was mordant, it was militant and it was a truth-telling magazine.... Two things it was not, however, were literary and cultural. So we had something to contribute." ${ }^{133}$ As Grief describes it, The Baffler was just as influential for $n+1$ as it was for Eggers and McSweeney's, if not more so.

These quotations might lead some to consider The Baffler to be a hole in my archive; that the group I have sought to trace would be better named "The Baffler Group," instead of The McSweeney's Group, which I have used. I might even agree with them were it not for two major roadblocks standing in the way. The first of these roadblocks is that actor-network theory according to Latour has limitations placed upon it. Specifically, in order to trace a network there has to be interviews, narratives, or commentary given on that group. Essentially, there has to be a paper trail that can be followed; actor-network theory does not allow for guesses or assumptions. There simply

\footnotetext{
132 Soudavar, "Interview with Dave Eggers."

133 Grief, "Little Voice.”
} 
is not the paper trail leading back to The Baffler that there is with McSweeney's. The Baffler did not publish their business plans, as McSweeney's did, for every little magazine to see, and there has not been the same number of interviews or articles written on The Baffler and its influence as there has been with McSweeney's. Therefore, in order to make the claim that The Baffler is the true starting point to this wave of contemporary little magazines, a large amount of guesswork would be required—something that actornetwork theory simply does not allow.

The second roadblock is that The Baffler folded after eight years—although it has since been revived - and it has rarely been published regularly. Thus, it becomes clear that The Baffler, although influential in terms of content, never had the successful business model that McSweeney's did. McSweeney's has been the major influence on this new wave of little magazines not only because of its influential content, but also, and more importantly, because it provided a successful model for how a print publication could survive and succeed in an increasingly digital age. Each of the major magazines covered in this work-McSweeney's, The Believer, and $n+1$-have adopted that model and never folded like The Baffler did. Due to this, it cannot be claimed that The Baffler was more influential on little magazines than McSweeney's has been.

Intriguingly, a different issue arises if other magazines are brought up to challenge McSweeney's influence. Both The Believer and $n+1$ have noted that the Partisan Review was a huge influence when those magazines began. The reference of the Partisan Review proves problematic for my project because it further complicates finding the original source of influence. Surely, the Partisan Review could reference its own influences, just as $n+1$ and The Believer have. In addition, those magazines that 
influence the Partisan Review surely had influences as well. If I attempted to trace the influences of every magazine that its successor had cited as an influence, the project would grow exponentially. Where does it (or can it) end?

However, the citation of the Partisan Review as an influence by both The Believer and $n+1$ also directly connects the magazines of The McSweeney's Group back to the first golden age of little magazines, which confirms the value of my project. By citing a magazine like the Partisan Review, these contemporary magazines are knowingly continuing in a rich tradition. Therefore, these contemporary magazines are the heirs to the history of the little magazines of the first golden age. The connection to the little magazines of the modernist era validates both the methodology used for my project and the assertion of value in analyzing contemporary little magazines in the same vein that Scholes, Wulfman, and others have used with the modernist little magazines. 


\section{REFERENCES}

“A Regressive Avant-Garde.” $n+1$, Fall 2004, 7-9.

Adams, Lorraine. "The Write Stuff." American Prospect 14, no. 2 (2003): 39-41.

Amsden, David. "The believer." Salon, March 9, 2005.

http://www.salon.com/2005/03/09/eggers_37/.

Atkinson, Michael. “O Biblioklepts!” The Believer, May 2003, 55-62.

Blackwell, Stephen. "Dave Eggers is a Luddite.” Death and Taxes, February 7, 2011. http://www.deathandtaxesmag.com/51000/dave-eggers-is-a-luddite/.

Bennett, Paul. "We are in a State of Oklahoma." Might Magazine, February/March 1996, 10 .

Benson, Heidi. "The War on Snark.” San Francisco Chronicle, July 13, 2003.

http://www.sfgate.com/magazine/article/THE-WAR-ON-SNARK-THE-BELIEVER-Alittle-2602985.php\#page-2.

Burn, Gordon. "The believers." The Guardian, March 26, 2004.

http://www.guardian.co.uk/books/2004/mar/27/fiction.zadiesmith.

De la Manzana,Tobias. “Jack White.” The Believer, May 2003, 74-77.

Doran, D’Arcy. “Beyond the Lattice.” Huck, April/May 2013, 20-28.

Eggers, Dave. A Heartbreaking Work of Staggering Genius. New York: Vintage Books, 2000 .

—_. “Copyright Page.” Timothy McSweeney’s Quarterly Concern, Autumn 1998.

_. "Copyright Page.” Timothy McSweeney's Quarterly Concern, Late Summer/Early Fall 1999.

_ “Copyright Page.” Timothy McSweeney's Quarterly Concern, Late Winter/Early Spring 1999.

—_. "Copyright Page.” Timothy McSweeney’s Quarterly Concern, Summer 2000.

—_. "Making It Up as We Go Along." ESPN.go.com. n.d. http://sports.espn.go.com/espnmag/story?id=3288256.

"Editorial Statement." $n+1$, Fall 2004, 3. 
Evans, Brad. "Introduction to Le Petit Journal Des Refusees." The Modernist Journals Project. n.d.

http://www.modjourn.org/render.php?view=mjp_object\&id=1183478160359375.

Franklin, Ruth. "The 98-Pound Gorilla in the Room." Slate. The Washington Post Company, 3 Apr. 2003. Web. 10 Nov. 2012.

Foster, Ken. "Red Dresses.” Timothy McSweeney's Quarterly Concern, Late Summer/Early Fall 1999, 129-134.

Gessen, Keith. "Does n+1 have beef with Dave Eggers?" Big Think, May 13, 2008. http://bigthink.com/videos/does-n1-have-beef-with-dave-eggers.

—_. "Eggers, Teen Idol; or, The Education of Gary Baum." n+1, Fall 2004, 39-61.

Greif, Mark. "Little Voice." New Statesman 141, no. 5102 (2012): 42-43.

"Guidelines for Quarterly Submissions." McSweeney's Internet Tendency. n.d. http://www.mcsweeneys.net/pages/guidelines-for-quarterly-submissions.

Guthrie, Julian. "Panorama seeks to expand reach of newspapers." San Francisco Chronicle, November 24, 2009. http://www.sfgate.com/news/article/Panorama-seeks-toexpand-reach-of-newspapers-3280601.php.

Habash, Gabe. "Literary Magazines Adapt to the Digital Age." Publishers Weekly 260, no. 10 (2013): 4-5.

Hamilton, Caroline D. One Man Zeitgeist: Dave Eggers, Publishing and Publicity. New York and London: Continuum, 2010.

Hungerford, Amy. "McSweeney's and the School of Life." Contemporary Literature 53, no. 4 (2012): 646-680.

“Idea Share.” The Believer, March 2003, 16.

Julavits, Heidi. "Rejoice! Believe! Be Strong and Read Hard!” The Believer, March 2003, $3-15$.

Knobel, Lance. "The Little Journal That Grew Big." Eye 20, no. 78 (2010): 28-35.

La Farge, Paul. "The Little Nicholson Baker in My Mind." The Believer, March 2003, $17-23$. 
Latham, Sean, and Robert Scholes. "The Rise of Periodical Studies." PMLA 121, no. 2 (2006): 517-31.

Latour, Bruno. Reassembling the Social: An Introduction to Actor-Network-Theory. Oxford: Oxford UP, 2005. Print.

Leveridge, Brett. "Men My Mother Dated.” Might Magazine, February/March 1996, 11.

Marcus, Ben. "Literary Enhancement Through Food Intake: A Dietary Guideline for Reading." Timothy McSweeney's Quarterly Concern, Summer 2000, 165-174.

Marek, Jane E. Women Editing Modernism: “Little” Magazines and Literary History. Lexington: University Press of Kentucky, 1995.

Merritt, Stephanie. "A Bloomsbury set for the podcast age." The Observer, March 31, 2007. http://www.theguardian.com/media/2007/apr/01/pressandpublishing.books.

Park, Ed. "Like Cormac McCarthy, But Funny.” The Believer, March 2003, 49-59.

Philpotts, Matthew. "The Role of the Periodical Editor: Literary Journals and Editorial Habitus." The Modern Language Review 107, no. 1 (2012): 39-64.

Preston, John. "Dave Eggers interview: the heartbreak kid." The Telegraph, December 29, 2009. http://www.telegraph.co.uk/culture/books/6865365/Dave-Eggers-interview-theheartbreak-kid.html.

Pruzan, Todd. “Oddi Jobs.” Print 60, no. 3 (2010): 88-93.

“Rhyme Time!” Might Magazine, February/March 1996, 10.

Roth, Marco. "Revenge of the Regressive Avant-Garde." nplusonemag,com, May 6, 2005. http://nplusonemag.com/revenge-regressive-avant-garde.

Scholes, Robert, and Clifford Wulfman. Modernism in the Magazines: An Introduction. New Haven: Yale UP, 2010. Print.

Scott, A.O. "Among the Believers." The New York Times, September 11, 2005. http://www.nytimes.com/2005/09/11/magazine/11BELIEVERS.html?pagewanted=all\& $\underline{\mathrm{r}=0}$

Shahum, Leah. "Media Picks,” Mother Jones, July/August 1997. http://www.motherjones.com/media/1997/07/media-picks.

Shulevitz, Judith. "Too Cool for Words." The New York Times, May 6, 2001. http://www.nytimes.com/books/01/05/06/bookend/bookend.html. 
Siegal, Nina. "Dave Eggers.” The Progressive 71, no. 11 (2007): 33-37.

Soudavar, Saadi. “An Interview with Dave Eggers.” Armchairnews.com. April 28, 2000. http://www.armchairnews.com/freelance/eggers.html.

Tawa, Renee. "New magazine has an abiding faith in the good book review." Los Angeles Times, March 31, 2003.

http://articles.latimes.com/2003/mar/31/entertainment/et-renee31.

Thomas, Susan E. "Zeroing In on Contemporary, Independent Visual Arts Magazines." Art Documentation: Journal of the Art Libraries Society of North America 26, no. 1 (2007): 40-50.

“Timothy McSweeney’s Quarterly Concern.” McSweeney's Quarterly \& Books. n.d., http://www.mcsweeneys.net/books\#about.

Wolff, Michael. "The Kidder King." New York Magazine, November 13, 2000.

http://nymag.com/nymetro/news/media/columns/medialife/4037/ 